\title{
PEPPSI-type palladium complexes containing basic 1,2,3-triazolylidene ligands and their role in Suzuki-Miyaura catalysis
}

\author{
Daniel Canseco-Gonzalez, ${ }^{[a]}$ Andrzej Gniewek, ${ }^{[b]}$ Michal Szulmanowicz, ${ }^{[b]}$ Helge Müller-Bunz, ${ }^{[a]}$ \\ Anna M. Trzeciak, ${ }^{*[b]}$ and Martin Albrecht**a]
}

\begin{abstract}
A series of PEPPSI-type palladium(II) complexes were synthesized that contain 3chloropyridine as an easily removable ligand and a triazolylidene as a strongly donating mesoionic spectator ligand. Catalytic tests in Suzuki-Miyaura crosscoupling reactions revealed activity of these complexes towards aryl bromides and aryl chlorides at moderate temperatures $\left(50{ }^{\circ} \mathrm{C}\right)$. However, the impact of steric shielding was inverse to that observed with related normal $\mathrm{N}$ -
\end{abstract}

homogeneous catalysts for the arylation of aryl halides. Obviously, the substitution of a normal N-heterocyclic carbene for a more basic triazolylidene ligand in the pre-catalyst has a profund impact on the mode of action of the catalytic system.

Keywords: palladium $\cdot$ mesoionic
carbene $\cdot$ cross-coupling $\cdot$
heterogeneous catalysis
homogeneous catalysis

\section{Introduction}

Palladium complexes have found widespread academic and industrial application as catalyst precursors for carbon-carbon crosscoupling, and for $\mathrm{C}-\mathrm{N}$ and $\mathrm{C}-\mathrm{O}$ bond formation reactions. ${ }^{[1]}$ Typically, a $\mathrm{C}-\mathrm{X}$ bond ( $\mathrm{X}=$ halide or pseudohalide) is required in the carbon precursor, though recently, also substantial progress has been accomplished for the direct functionalization of $\mathrm{C}-\mathrm{H}$ bonds. ${ }^{[2]}$ Cross-coupling of cheap and readily available chlorocarbons $(\mathrm{X}=$ $\mathrm{Cl})$ generally involves oxidative addition of the $\mathrm{C}-\mathrm{Cl}$ bond to a lowvalent and coordinatively unsaturated palladium species as ratelimiting step. ${ }^{[3]}$ Appropriate balancing of the stability of the critical palladium(0) species is thus an essential aspect for designing better catalysts. The stability should be high enough to prevent decomposition, yet sufficiently low to favor oxidative $\mathrm{C}-\mathrm{Cl}$ addition. Following these generic guidelines, ligands with enhanced basicity and steric demand were developed over the last years that indeed spurred the catalytic activity of the palladium center, including $\mathrm{P}(o-$ tol $)_{3},{ }^{[4]} \mathrm{P}(t \mathrm{Bu})_{3}{ }_{3}{ }^{[5]} \mathrm{PCy}_{2}$ (biaryl), ${ }^{[6]}$ and IMes (IMes $=1,3$-dimesitylimidazol-2-ylidene). ${ }^{[7]}$ In particular, the combination of IMes as a strongly electron-donating and bulky N-heterocyclic carbene (NHC) with 3-chloropyridine as easily removable ligand at $\mathrm{PdCl}_{2}$ gave a highly active catalyst precursor for cross-coupling reactions (A, Fig. 1) ${ }^{[8]}$ Because of the beneficial role of the pyridine ligand, the term PEPPSI (pyridine-enhanced precatalyst preparation, stabilization, and initiation) was coined.
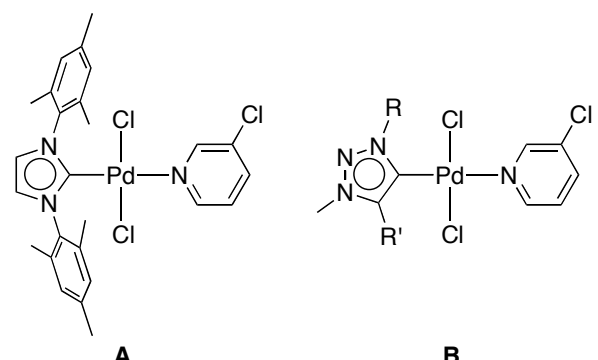

Figure 1. PEPPSI-type IMes palladium(II) complex $\mathbf{A}$ and its triazolylidene congener $\mathbf{B}$ $($ PEPPSI $=$ pyridine-enhanced precatalyst preparation, stabilization, and initiation). 
Recent work has shown that the electron donor properties of $\mathrm{N}$ heterocyclic carbene ligands ${ }^{[9]}$ substantially increase when the heteroatoms of the cycle are positioned at remote positions. ${ }^{[10]}$ For example, mesoionic ${ }^{[11]}$ 1,2,3-triazol-5-ylidenes (B, Fig. 1) bear only one nitrogen adjacent to the carbene bonding site and are more basic than classical imidazol-2-ylidene NHCs. ${ }^{[12]}$ Such triazolylidenes ${ }^{[13]}$ have recently been applied for the development of a variety of different catalytic systems. ${ }^{[14]}$ The preparation of these ligands is highly versatile since the triazolium ligand precursor is readily available through copper-catalyzed [2+3] cycloaddition ('click chemistry' $)^{[15]}$ and subsequent $\mathrm{N}$-alkylation. The synthetic flexibility paired with the stronger electron donor properties suggests that these ligands facilitate $\mathrm{C}-\mathrm{Cl}$ oxidative addition in cross-coupling chemistry. Based on these considerations, we became interested in synthesizing a set of PEPPSI-type palladium complexes B with different triazolylidene ligands, and in evaluating their catalytic activity. Remarkably, the modification of the heterocyclic carbene ligand has a profound impact on the working mode of the catalyst, which may be rationalized by a decreased $\mathrm{Pd}-\mathrm{C}_{\text {carbene }}$ bond stability in the triazolylidene system. ${ }^{[16]}$

\section{Results}

Synthesis of the complexes. The triazolium salts 1a-e were convenienly accessible via conventional and versatile $\mathrm{Cu}$-catalyzed 'click' cycloaddition of the appropriate azide and alkyne, followed by chemoselective methylation of the N3 position using MeI (Scheme 1). ${ }^{[17]}$ Metalation of the triazolium salts with $\operatorname{Ag}_{2} \mathrm{O}$ and subsequent transpalladation in 3-chloropyridine as solvent afforded the PEPPSI-type palladium complexes $\mathbf{3 a - e}$ as air- and moisturestable solids. Yields of pure material ranged between $20 \%$ and $60 \%$ only, partially because of the formation of an insoluble pale yellow side product, and partially because product fractions were washed off during purification. The complexes are well-soluble in chlorinated solvents, and also dissolve substantially in $\mathrm{Et}_{2} \mathrm{O}$ and similar low-polarity solvents that are typically used for precipitation of organometallic compounds.

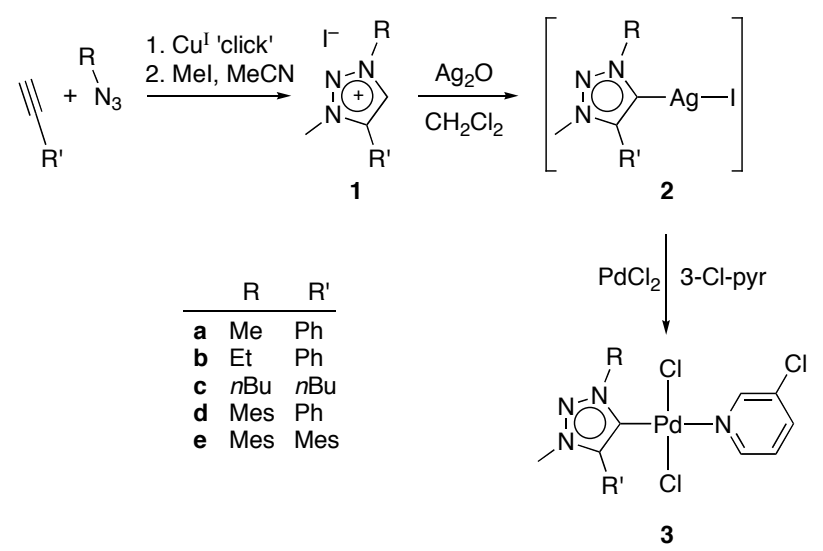

Scheme 1. Synthesis of complexes 3

Successful palladation was indicated spectroscopically by the absence of the low-field triazolium proton resonance in the ${ }^{1} \mathrm{H}$ NMR spectrum, and by the presence of the diagnostic set of four resonances due to the 3-chloropyridine ligand in stoichiometric quantities. In addition the resonance of the $\mathrm{N} 3$-bound $\mathrm{CH}_{3}$ group is shifted upfield by $0.3-0.4 \mathrm{ppm}$ while the $\alpha$-protons of the N1-bound alkyl group become more shielded (complexes 3a-c). In contrast, the ${ }^{13} \mathrm{C}$ NMR resonances are barely affected by the palladation. The chemical shift difference of the $\mathrm{C} 5$ nucleus shifts between 0.2 and 8 ppm upon changing its substituent from hydrogen (in 1) to palladium (in 3), and the $\mathrm{C} 4$ frequency did not vary by more than 1 ppm. The absolute chemical shift of the C5 nucleus does not correlate with the electronic impact of the ortho substituents at $\mathrm{N} 1$ and $\mathrm{C} 4{ }^{[18]}$ suggesting that the resonance frequency is governed by a combination of steric and electronic factors.

Complexes 3b, 3c, and 3d were analyzed by single crystal X-ray diffraction (Fig. 2). In all three complexes, the ligands around the square-planar palladium center adopt the expected trans arrangement. The $\mathrm{Pd}-\mathrm{C}_{\mathrm{trz}}$ bond length in all complexes is 1.96(1) $\AA$, which is in line with related triazolylidene palladium complexes. ${ }^{[14 e, f, 19]}$ The $\mathrm{Pd}-\mathrm{N}_{\text {pyr }}$ bond distance is weakly affected by the substitution pattern on the triazolylidene ligand and increases slightly along the series $\mathbf{3 b}<\mathbf{3} \mathbf{c}<\mathbf{3 d}$. The effect is very small and may indicate an enhanced steric congestion along this series. The most pronounced distinction between the three complexes pertains to the different twist of the heterocycles out of the palladium coordination plane. The dihedral angle of the two heterocycles is nearly identical in $\mathbf{3 b}$ and $\mathbf{3 c}, 30.6(2)^{\circ}$ and $27.57(16)^{\circ}$, respectively, yet significantly larger for $\mathbf{3 d}, 68.2(3)^{\circ}$. The almost perpendicular arrangement is probably a direct conseqeuence of the shielding properties of the ortho methyl groups of the mesityl substituent in 3d. This shielding factor may also explain the fact that the torsion of the pyridine ligand out of the metal plane is smallest for $\mathbf{3 d}$ $\left(29.3(3)^{\circ}\right)$, and increases for $\mathbf{3 c}\left(36.54(11)^{\circ}\right)$ and $\mathbf{3 b}\left(45.55(13)^{\circ}\right)$. In all three complexes, the dihedral angle between the palladium square plane and the triazolylidene ligand is significantly larger (68$79^{\circ}$ ) than the $29-46^{\circ}$ between the palladium coordination plane and the pyridine heterocycle.

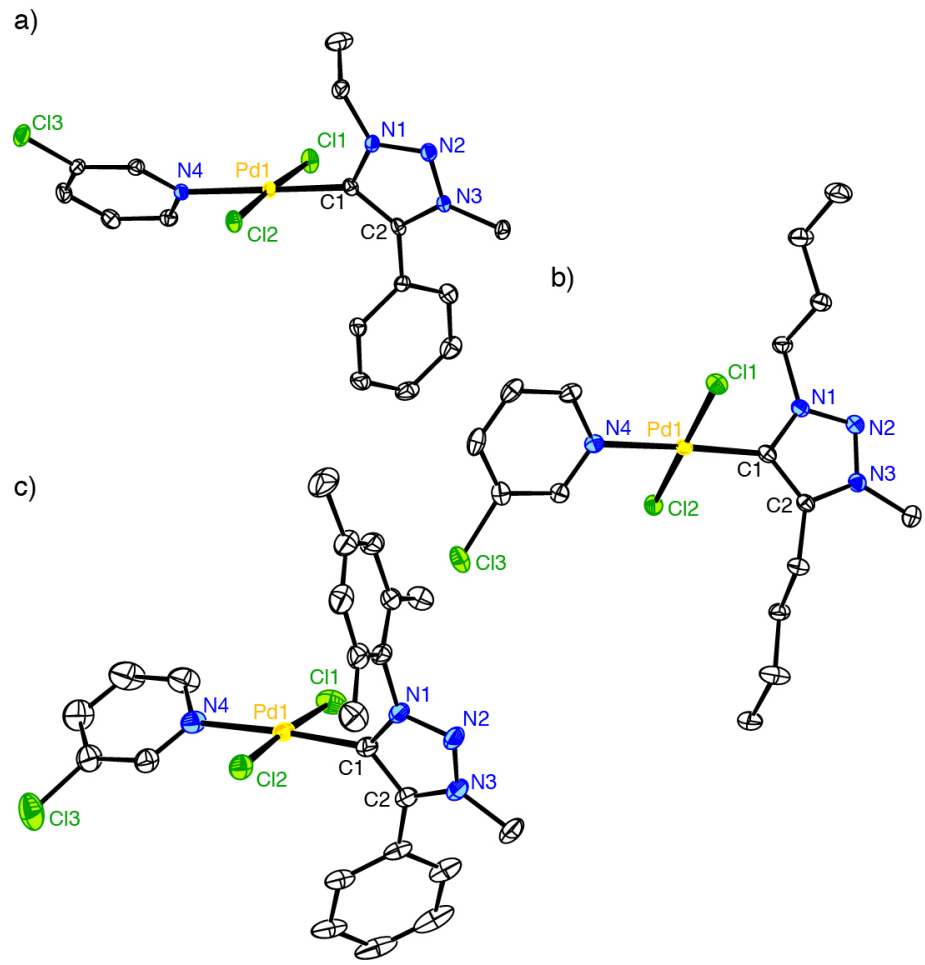

Figure 2. ORTEP plots of complex $\mathbf{3 b}$ (a), 3c (b), and one of the two crystallographically independent molecules of complex 3d (c) (50\% probablility level; co-crystallized solvent molecules and hydrogen atoms omitted for clarity). 
Table 1. Selected bond lengths $(\AA)$ and angles $\left({ }^{\circ}\right)$ for complexes $\mathbf{3 b}, \mathbf{3 c}$, and $\mathbf{3 d}$.

\begin{tabular}{lrrrr}
\hline & 3b & 3c & \multicolumn{2}{c}{ 3d } \\
& & & molecule 1 & ${\text { molecule } 2^{[\mathrm{a}]}}^{-}$ \\
$\mathrm{Pd}-\mathrm{C}(1)$ & $1.9601(16)$ & $1.9650(13)$ & $1.957(3)$ & $1.967(3)$ \\
$\mathrm{Pd}-\mathrm{N}(4)$ & $2.1105(13)$ & $2.1192(11)$ & $2.129(3)$ & $2.126(3)$ \\
$\mathrm{Pd}-\mathrm{Cl}(1)$ & $2.3028(4)$ & $2.3103(3)$ & $2.3115(8)$ & $2.2961(9)$ \\
$\mathrm{Pd}-\mathrm{Cl}(2)$ & $2.3051(4)$ & $2.3054(3)$ & $2.3046(9)$ & $2.2969(9)$ \\
$\mathrm{C}(1)-\mathrm{Pd}-\mathrm{N}(4)$ & $178.87(6)$ & $177.70(4)$ & $175.81(11)$ & $178.71(12)$ \\
$\mathrm{C}(1)-\mathrm{Pd}-\mathrm{Cl}(1)$ & $88.63(5)$ & $89.27(4)$ & $88.18(10)$ & $89.63(9)$ \\
$\mathrm{N}(4)-\mathrm{Pd}-\mathrm{Cl}(1)$ & $90.45(4)$ & $91.83(3)$ & $92.12(8)$ & $89.76(9)$ \\
$\mathrm{C}(1)-\mathrm{Pd}-\mathrm{Cl}(2)$ & $88.68(5)$ & $88.67(4)$ & $88.76(10)$ & $90.23(9)$ \\
$\mathrm{N}(4)-\mathrm{Pd}-\mathrm{Cl}(2)$ & $92.25(4)$ & $90.36(3)$ & $90.75(8)$ & $90.48(9)$ \\
$\mathrm{Cl}(1)-\mathrm{Pd}-\mathrm{Cl}(2)$ & $176.732(16)$ & $175.849(12)$ & $176.04(3)$ & $174.89(4)$ \\
\hline
\end{tabular}

[a] second independent molecule in the unit cell, atom labeling adapted.

Catalytic application. The PEPPSI-type complexes were tested as catalyst precursors in Suzuki-Miyaura cross-coupling reactions using $m$-bromoanisole and phenylboronic acid as model substrates. A first set of experiments aimed at identifying most suitable reaction conditions to achieve this coupling at mild reaction temperatures (50 $\left.{ }^{\circ} \mathrm{C}\right)$. The activity of complex $\mathbf{3} \mathbf{b}$ was evaluated by determining the conversion after $2 \mathrm{~h}$. Initial variation included the solvent (DMA, dioxane, and $i \mathrm{PrOH})$, and the base $\left(\mathrm{K}_{2} \mathrm{CO}_{3}, \mathrm{NaOAc}, t \mathrm{BuOK}\right.$, and $\mathrm{Bu}_{4} \mathrm{NF}$; Table 2). These experiments indicated best performance with $\mathrm{Bu}_{4} \mathrm{NF}$ in $i \mathrm{PrOH}$, and further catalytic evaluations were thus carried out using this combination only. The reaction is sensitive to thermal variations. At $50{ }^{\circ} \mathrm{C}$, catalytic the solution remained transparent over extended periods of time. When heated to $80^{\circ} \mathrm{C}$, however, the catalytic reaction mixture became turbid within the first $10 \mathrm{~min}$, and a black precipitate started to gradually appear. In contrast, reducing the temperature to $30{ }^{\circ} \mathrm{C}$ preserved the transparent appearance yet compromised the conversion significantly ( $33 \%$ after 2 h, $58 \%$ after 4 h).

Table 2. Conversion (\%) of 3-bromoanisole in the Suzuki-Miyaura cross-coupling catalyzed by $3 \mathbf{b} \cdot{ }^{[a]}$

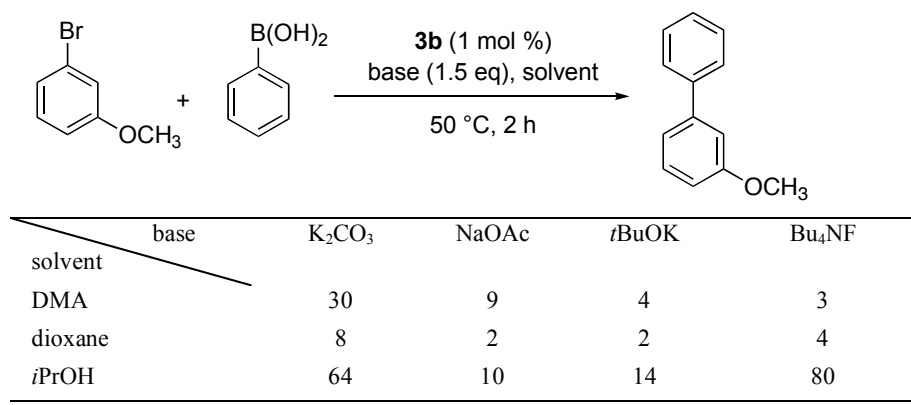

[a] general conditions: bromoanisole $(1.0 \mathrm{mmol}), \mathrm{PhB}(\mathrm{OH})_{2}(1.2 \mathrm{mmol})$, base $(1.5$ $\mathrm{mmol})$, and complex $\mathbf{3 b}(5 \mu \mathrm{mol}, 0.5 \mathrm{~mol} \%)$ in appropriate solvent $(3.0 \mathrm{~mL})$ at $50{ }^{\circ} \mathrm{C}$ for $2 \mathrm{~h}$.

The role of the pyridine ligand as activator was investigated by comparing the activity of $\mathbf{3 b}$ to related complexes $\mathbf{4}$ and $\mathbf{5}$ (see chart). Complex $\mathbf{4}$ is a dimeric version of $\mathbf{3 b}$ that may split into two coordinatively unsaturated $\left[\mathrm{Pd}(\operatorname{trz}) \mathrm{X}_{2}\right]$ fragments akin to the intermediate expected upon pyridine dissociation from complex $\mathbf{3} \mathbf{b}$. Under the optimized reaction conditions, complex $\mathbf{4}$ exhibits a lower catalytic activity and reaches only $60 \%$ conversion. ${ }^{[17]}$ Complex 5 comprising two triazolylidene ligands gave an appreciable $75 \%$ conversion, only marginally lower than the conversions achieved with complex $\mathbf{3 b}{ }^{[20]}$ The high activity of complex $\mathbf{5}$ is in agreement with earlier studies on an analoguous complex derived from $\mathbf{1} \mathrm{e}^{[14 \mathrm{~b}]}$
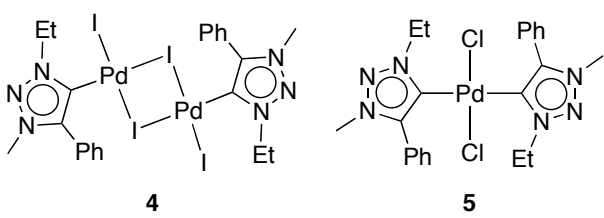

and may be related to that observed for a mixed C2-/C4-bound bis(imidazolylidene) system, ${ }^{[21]}$ in which the C4-bound imidazolylidene is supposed to be less strongly bound to the palladium center than the C2-bound analogue. ${ }^{[22]}$ In complex 5, one triazolylidene ligand may thus mimic the activating role of $\mathbf{3}$-chloropyridine in $\mathbf{3 b}$, thus generating a $\left[\mathrm{Pd}(\operatorname{trz}) \mathrm{X}_{2}\right]$ species as well.

Variation of the substituents at the triazolylidene ligand revealed a moderate dependence on steric factors (Fig. 3). The smallest substituents (3a and $\mathbf{3 b}$ ) induced the highest active whereas the di(mesityl)-substituted triazolylidene palladium complex $\mathbf{3 e}$ displayed comparably slow conversion. For example, 35\% conversion were reached with complex 3a after $15 \mathrm{~min}$, while 60 min were required with $\mathbf{3 e}$ to accomplish the same turnover. The low performance of $\mathbf{3 e}$ is remarkable when considering the excellent catalytic activity of its imidazol-2-ylidene analogue ( $c f \mathbf{A}$, Fig. 1). ${ }^{[8,23]}$ Complexes $\mathbf{3 c}$ and $\mathbf{3 d}$ comprised of moderately demanding triazolylidene substituents display activities that are intermediate compared to 3a and 3e. These results suggest that the bulkiness around the palladium center matters, either for catalyst activation, or for substrate conversion.

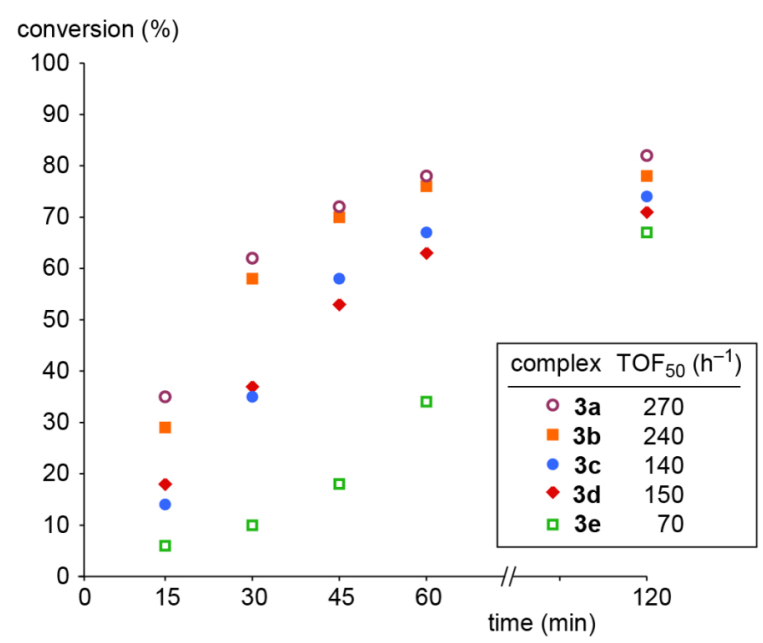

Figure 3. Time-conversion profile for the coupling of bromoanisole $(1.0 \mathrm{mmol})$ and phenylboronic acid $(1.2 \mathrm{mmol})$ catalyzed by complex $3(0.5 \mathrm{~mol} \%)$ with $\mathrm{Bu}_{4} \mathrm{NF}(1.5$ $\mathrm{mmol})$ in $i \mathrm{PrOH}(3 \mathrm{~mL})$ at $50{ }^{\circ} \mathrm{C}$; inset shows approximate turnover frequencies at $50 \%$ conversion $\left(\mathrm{TOF}_{50}\right)$.

The most active complexes $\mathbf{3} \mathbf{a}$ and $\mathbf{3 b}$ were subsequently tested for the conversion of more demanding aryl chlorides. With $p$ chlorobenzaldehyde as substrate, the activity of 3a containing a small Me substituent at the triazolylidene ligand was distinctly higher than that of $\mathbf{3 b}$. At $50{ }^{\circ} \mathrm{C}$ and at a 2 mol\% loading of palladium complex $v s$ aryl chloride, $\mathbf{3 a}$ gave appreciable catalytic activity with a turnover frequency at $50 \%$ conversion, $\mathrm{TOF}_{50}=53 \mathrm{~h}^{-1}$. In contrast, complex $\mathbf{3 b}$ comprising an ethyl ortho substituent at the triazolylidene was markedly less active $\left(\mathrm{TOF}_{50} 17 \mathrm{~h}^{-1}\right)$. With both complexes, conversion ceased at about $60 \%$ conversion, which suggests a limited lifetime of the catalytically active species. No improvement was achieved when increasing the loading of the catalyst precursor from $2 \mathrm{~mol} \%$ to $5 \mathrm{~mol} \%$. 
Mechanistic insights. Aryl chloride conversion under relatively mild conditions as applied here typically suggests homogeneous catalysis. ${ }^{[24]}$ However, the delicate impact of the temperature as well as the trend observed in the steric demand of the triazolylidene ligand, which is inverse to the trend observed for normal NHC palladium complexes, ${ }^{[8]}$ suggest a catalytic mechanis that differs from classical PEPPSI-type systems. In order to further elucidate the mode of action, a set of analyses was performed including microscopy, mass spectrometry, and mercury poisoning experiments. ${ }^{[25]}$ In a representative experiment using complex $\mathbf{3 b}$ under standard conditions (bromoanisole as substrate, $c f$ Fig. 3), a large excess elemental mercury (ca. 7 g, $35 \mathrm{mmol}$, ca. 7,000 molequiv $v s$ palladium) was added after 5 min ( $14 \%$ conversion). This addition efficiently stalled the catalytic activity, and the same $14 \%$ conversion were determined after $120 \mathrm{~min}$. In contrast, a parallel mercury-free reaction reached $80 \%$ over the same period. The outcome was qualitatively identical when the substrate was replaced with chlorobenzaldehyde. Addition of mercury after $5 \mathrm{~min}$ (4\% conversion) inhibited further catalytic coupling and no biaryl product was formed during the subsequent $120 \mathrm{~min}$ ( $c f 47 \%$ yield in a parallel unpoisoned run over the same time span). These results indicate that the catalytic working mode is not fundamentally different when changing the substrate from aryl bromides to aryl chlorides. Moreover, the well-known capability of mercury to poison heterogeneous but not homogeneous catalysts ${ }^{[26]}$ is in apparent contradiction with the assumption that palladium-catalyzed cross-coupling of aryl chlorides under mild conditions requires molecular palladium. ${ }^{[1,24]}$

Analysis of catalytic reaction mixtures by transmission electron microscopy (TEM) revealed further details. A micrograph of a sample taken from the cross-coupling of bromoanisole using $\mathbf{3 b}$ after 35 min (Fig. 4a) is representatitive for all complexes $\mathbf{3 a - e}$ and indicates the formation of palladium nanoparticles with an average size of 2-3 nm. Slightly larger particles formed in the conversion of chlorobenzaldehyde (3-5 nm when using 3a, Fig. 4b). Nanoparticle formation was also observed when either of the two coupling partners was omitted. In the absence of phenylboronic acid, the particles were consistently larger $(4-8 \mathrm{~nm})$. In addition, some redispersion was noted by the presence of larger crystallites, suggesting Ostwald ripening under these conditions. In the absence of the aryl halide, the particle size does not differ significantly from that of the original catalytic mixture, which suggests that the phenylboronic acid may play a role in stabilizing the nanoparticles and in controlling their size. The observed Ostwald ripening may provide an explanation for the catalytic activity of the system, as the particle size redistribution requires a partial dissolution of particles, thus generating a dissolved palladium(0) species $^{[27]}$ that either undergoes oxidative addition with an aryl halide and thus enters the

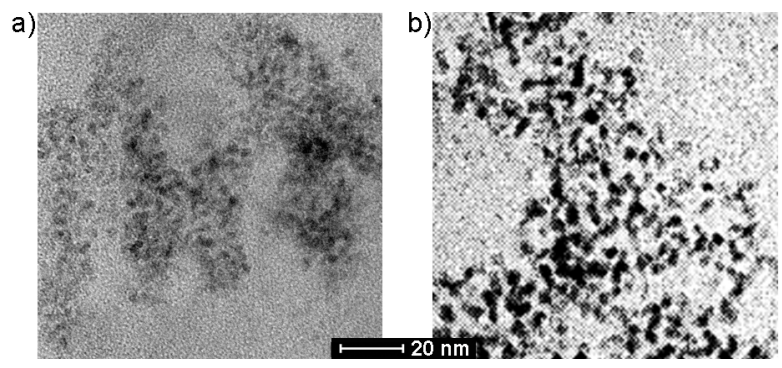

Figure 4. TEM micrographs of post-reaction mixtures after Suzuki-Miyaura reaction with a) $\mathbf{3 b}$ and bromoanisole, b) $\mathbf{3} \mathbf{a}$ and chlorobenzaldehyde. catalytic cycle, or aggregates with a nanoparticle to contribute to the Ostwald ripening process. ${ }^{[28]}$

Electron-spray ionization mass spectrometry (ESI-MS) measurements were performed to validate the mechanistic hypothesis. In agreement with the TEM data and with the formation of colloidal palladium(0), ESI-MS spectra of the catalytic reaction mixture did not show any signals in the low molecular range that would indicate the presence of defined molecular species. Irrespective of the sampling time (after 10, 20, and $35 \mathrm{~min}$ ), only signals in the $900-1600 \mathrm{~m} / \mathrm{z}$ range were detected. The spectra were almost identical for all complexes 3a-e and do not indicate a correlation to the observed catalytic conversions. For example when using complex 3b, signals at 1020, 1443, 1490, and $1534 \mathrm{~m} / \mathrm{z}$ were measured. Their isotopic distribution pattern indicates the presence of up to 4 palladium atoms per species. Moreover, the 1443 and $1490 \mathrm{~m} / \mathrm{z}$ signals were also observed when using different triazolylidene palladium complexes as catalyst precursors, which suggests that these species do not contain a triazolylidene ligand. In contrast, ESI-MS measurements on $i \mathrm{PrOH}$ solutions containing only the complex and neither cross-coupling substrates nor $\mathrm{Bu}_{4} \mathrm{NF}$ revealed signals for various low-molecular weight species resulting from loss of chloride, and from triazolylidene ligand transfer. For example, a solution of $\mathbf{3 b}$ gave signals at $479.1 \mathrm{~m} / \mathrm{z}$, attributed to $[\mathrm{Pd}(\operatorname{trz})(\mathrm{py}-\mathrm{Cl}) \mathrm{Cl}]^{+}$and at $517.1 \mathrm{~m} / \mathrm{z}$, assigned to $\left[\mathrm{Pd}(\operatorname{trz})_{2} \mathrm{Cl}\right]^{+}$. The latter species again underlines the activating role of the chloropyridine ligand. Transfer of the triazolylidene ligand may be a consequence of the sample ionization in the mass spectrometer, since no indications for ligand transfer were obtained from NMR solution measurements. Similar effects were observed previously with imidazolylidene palladium complexes. ${ }^{[29]}$ Warming of a $i \mathrm{PrOH}$ solution of $\mathbf{3 b}$ to $50{ }^{\circ} \mathrm{C}$, i.e. to the catalytic reaction temperature, resulted in substantially more signals in the ESI-MS spectra, including dimeric species such as $\left[\mathrm{Pd}_{2}(\operatorname{trz})_{3} \mathrm{Cl}_{3}\right]^{+}(880.1 \mathrm{~m} / \mathrm{z})$ and $\left[\mathrm{Pd}_{2}(\operatorname{trz})_{3}(\mathrm{py}-\mathrm{Cl})_{2} \mathrm{Cl}_{3}+3 \mathrm{H}\right]^{4+}(1109.2 \mathrm{~m} / \mathrm{z})$. The increased number of species and the presence of dimetallic systems that were not detected when keeping the solution at room temperature suggests that the complexes are thermally unstable. Indeed, ${ }^{1} \mathrm{H}$ NMR monitoring of the stability of $\mathbf{3 b}$ in $i \mathrm{PrOD}-d_{8}$ at $50^{\circ} \mathrm{C}$ using hexamethylbenzene as internal standard revealed a drop of the concentration of $\mathbf{3 b}$ to $57( \pm 1) \%$ after $2 \mathrm{~h}$. In addition, a yellow precipitate was formed, but no palladium black. No further decrease was observed upon prolonged heating.

\section{Discussion}

The interplay of NHC metal complexes and nanoparticles has received much attention recently. Potentially related to our observations, degradation of NHC ruthenium complexes to nanoparticles in the presence of $\mathrm{N}$-heterocyclic carbenes has been reported. ${ }^{[30]}$ Moreover, it was shown that solid metal can be used as a precursor to generate a variety of molecular carbene metal complexes. ${ }^{[31]}$ Whilst imidazolium and ammonium salts effectively stabilize palladium nanoparticles and prevent their aggregation, ${ }^{[32]}$ ammonium salts were also demonstrated to facilitate the formation of soluble palladium species from palladium(0) nanoparticles in the presence of aryl halides. ${ }^{[33]}$ Taking these precedents into account, it seems plausible that colloidal palladium is the resting state of the catalyst derived from complex $3,^{[34]}$ though the catalytically active species ensues from dissociation of a cluster or single palladium atoms, either as a solvated palladium $(0)$ species, or as a triazolylidene adduct. 
Heterogenization of the molecular pre-catalyst to palladium nanoparticles and subsequent dissolution of palladium atoms from these nanoparticles constitutes a model that accounts for all the observations detailed above. Such a model has been suggested, though only rarely underpinned with experimental evidence. ${ }^{[35]}$ The dissociated 'naked' or triazolylidene-bound palladium atoms are expected to be sufficiently activated to oxidatively add both aryl bromides and aryl chlorides under mild conditions. ${ }^{[36]}$ Elemental mercury poisons the reaction by preventing dissociation of a palladium atom from the colloidal reservoir and thus shuts down the activation step from the catalyst resting state. In addition, $i \mathrm{PrOH}$ may be the solvent of choice because of its potentially reducing character, ${ }^{[37]}$ thus providing a smooth access to low-valent palladium. Formation of colloidal palladium may further explain the delicate role of the temperature, as elevated temperatures accelerate colloid formation and eventually lead to aggregation of the colloids to large particles that cannot easily expel a palladium atom. Too low temperatures in contrast appear to compromise the decomposition of the precursor complex 3, leading to low activity. Likewise, the substituents of the triazolylidene system may fulfill a role that is different from the steric protection of the metal center as in PEPPSItype imidazol-2-ylidene palladium catalysts $\mathbf{A}^{\left[{ }^{[8]}\right.}$ In the catalytic system described here, a low steric impact of the carbene ligand facilitates palladium dissociation, and little steric congestion also provides triazolium salts that may assist in stabilizing the palladium colloids. In addition to this effect on the catalytic reaction rate, ${ }^{[26 \mathrm{e}]}$ such stabilization is supposed to be essential to keep the nanoparticles small and to enhance the propensity of a palladium atom to dissociate from the particle and hence to enter the catalytic cycle.

\section{Conclusion}

We developed a straightforward synthetic methodology to obtain a series of C5-bound 1,2,3-triazolylidene palladium complexes comprising a 3-chloropyridine ligand as easily cleavable ligand. The activity of these complexes in Suzuki-Miyaura cross coupling can be tailored by varying the substituents of the triazolylidene ring. Steric effects govern the catalytic activity and less bulky substituents induce better catalytic activity than bulkier IMes-type analogues comprising two mesityl groups in ortho position, which contrasts the trends observed with the imidazol-2-ylidene congeners. Mechanistic work has demonstrated that the opposite trend originates from a fundamentally different mode of action of the triazolylidene complexes. In contrast to the homogeneous catalysis observed with the original PEPPSI system, all experimental evidence indicates that the triazolylidene complexes undergo a heterogenization process that generates palladium nanoparticles as the catalyst resting state. Leaching of palladium atoms from such nanoparticles provides a molecular, catalytically active species that is able to convert aryl chlorides under relatively mild conditions. Such a mechanism may be relevant for a range of catalyst precursors and care should be taken when using aryl chloride conversion as a probe, since spectator ligands may not be preserved but may be involved in a heterogenization-homogenization pathway and may or may not assist in reconstituting a dissolved active species from a colloidal reservoir. Moreover, this work highlights substantial differences between abnormal triazolylidenes and classical NHCs such as imidazol-2-ylidenes in metal bonding.
General. 1-methyl-4-phenyl-1,2,3-triazole, 1-mesityl-4-phenyl-1,2,3-triazole, the triazolium salt $\mathbf{1 c}$, and the silver carbenes $\mathbf{2 b}$ and $\mathbf{2 e}$ were described previously..$^{[12,14 b, 38]}$ All other reagents are commercially available were used as received. Microwave reactions were carried out using a Biotage Initiator 2.5, operating at $100 \mathrm{~W}$ irradiation power. Unless specified otherwise, NMR spectra were recorded at $25{ }^{\circ} \mathrm{C}$ on Varian Innova spectrometers operating at 300, 400 or $500 \mathrm{MHz}\left({ }^{1} \mathrm{H} \mathrm{NMR}\right)$ and 75,100 or 125 $\mathrm{MHz}\left({ }^{13} \mathrm{C}\{1 \mathrm{H}\} \mathrm{NMR}\right)$, respectively. Chemical shifts ( $\delta$ in ppm, coupling constants $J$ in $\mathrm{Hz}$ ) were referenced to residual solvent resonances. Assignments are based on homoand heteronuclear shift correlation spectroscopy. Elemental analyses were performed by the Microanalytical Laboratory at University College Dublin, Ireland, using a Exter Analytical CE-440 Elemental Analyzer.

General procedure for the synthesis of the triazolium iodides 1 . To a $\mathrm{MeCN}$ solution of triazole was added MeI and the mixture was stirred under microwave irradiation at $90{ }^{\circ} \mathrm{C}$ for $5 \mathrm{~h}$. All volatiles were then removed in vacuo. The residue was washed with copious amounts of $\mathrm{Et}_{2} \mathrm{O}$ several times and dried in vacuo to afford the crude triazolium salt 1 . Microanalytically pure samples were obtained by recrystallization from hot acetone. Analytical data for the new triazolium salts are compiled in the Supporting Information.

General procedure for the synthesis of the carbene silver complexes 2. To a solution of the triazolium salt 1 (1.0 eq) in $\mathrm{CH}_{2} \mathrm{Cl}_{2}$ was added $\mathrm{Ag}_{2} \mathrm{O}(0.5 \mathrm{eq})$. The mixture was stirred in the absence of light at room temperature for $2 \mathrm{~h}$ and filtered through Celite. The solvent was removed in vacuo at room temperature and the residue was washed with pentane $(3 \times 25 \mathrm{~mL})$ and dried in vacuo. Analytical data for the new triazolium salts are compiled in the Supporting Information.

General procedure for the synthesis of the carbene palladium complexes 3 . The carbene silver complex 2 and $\mathrm{PdCl}_{2}$ were suspended in 3-chloropyridine $(7 \mathrm{~mL})$ and stirred at $100{ }^{\circ} \mathrm{C}$ for $16 \mathrm{~h}$. The reaction mixture was cooled to RT, diluted with $\mathrm{CH}_{2} \mathrm{Cl}_{2}$ $(7 \mathrm{~mL})$ and passed through a short column of $\mathrm{SiO}_{2}$ covered with a pad of Celite. After product elution with $\mathrm{CH}_{2} \mathrm{Cl}_{2}$ was complete (TLC) were all volatiles evaporated under reduced pressure. The product was precipitated from pentane, collected by filtration, and dried in vacuo. The residue was dissolved in a minimum amount of $\mathrm{CH}_{2} \mathrm{Cl}_{2}$ and added into $\mathrm{Et}_{2} \mathrm{O}(50 \mathrm{~mL})$. The precipitate was removed by filtration and the filtrate was evaporated to dryness, thus affording pure complex 3 .

Complex 3a. The title product was obtained from 2a $(500 \mathrm{mg}, 0.61 \mathrm{mmol})$ of $\mathrm{PdCl}_{2}$ $(217 \mathrm{mg}, 1.23 \mathrm{mmol})$ according to the general procedure as a yellow solid $(200 \mathrm{mg}$, $35 \%) .{ }^{1} \mathrm{H}$ NMR $\left(\mathrm{CDCl}_{3} 500 \mathrm{MHz}\right): \delta 9.00\left(\mathrm{~d},{ }^{4} J_{\mathrm{HH}}=2.3 \mathrm{~Hz}, 1 \mathrm{H}, \mathrm{H}_{\mathrm{Py}}\right), 8.89\left(\mathrm{dd},{ }^{3} J_{\mathrm{HH}}=\right.$ $\left.5.5 \mathrm{~Hz},{ }^{4} J_{\mathrm{HH}}=1.2 \mathrm{~Hz}, 1 \mathrm{H}, \mathrm{H}_{\mathrm{Py}}\right), 7.93\left(\mathrm{dd},{ }^{3} J_{\mathrm{HH}}=8.1 \mathrm{~Hz},{ }^{4} J_{\mathrm{HH}}=1.4 \mathrm{~Hz}, 2 \mathrm{H}, \mathrm{H}_{\mathrm{Ar}}\right), 7.72$ $\left(\mathrm{ddd},{ }^{3} J_{\mathrm{HH}}=8.2 \mathrm{~Hz},{ }^{4} J_{\mathrm{HH}}=2.3 \mathrm{~Hz},{ }^{4} J_{\mathrm{HH}}=1.2 \mathrm{~Hz}, 1 \mathrm{H}, \mathrm{H}_{\mathrm{Py}}\right), 7.56\left(\mathrm{~m}, 3 \mathrm{H}, \mathrm{H}_{\mathrm{Ar}}\right), 7.28$ $\left(\mathrm{ddd},{ }^{3} J_{\mathrm{HH}}=8.2 \mathrm{~Hz},{ }^{3} J_{\mathrm{HH}}=5.5 \mathrm{~Hz},{ }^{5} J_{\mathrm{HH}}=0.4 \mathrm{~Hz}, 1 \mathrm{H}, \mathrm{H}_{\mathrm{Py}}\right), 4.59\left(\mathrm{~s}, 3 \mathrm{H}, \mathrm{NCH}_{3}\right), 3.98(\mathrm{~s}$, $\left.3 \mathrm{H}, \mathrm{NCH}_{3}\right) .{ }^{13} \mathrm{C}\left\{{ }^{1} \mathrm{H}\right\}$ NMR $\left(\mathrm{CDCl}_{3}, 125 \mathrm{MHz}\right): \delta 150.6\left(\mathrm{C}_{\mathrm{Py}}\right), 149.5\left(\mathrm{C}_{\mathrm{Py}}\right), 144.2\left(\mathrm{C}_{\mathrm{trz}}\right.$ $\mathrm{Ph}), 139.0\left(\mathrm{C}_{\mathrm{Py}}\right), 138.0\left(\mathrm{C}_{\mathrm{trz}}-\mathrm{Pd}\right), 132.7\left(\mathrm{C}_{\mathrm{Py}}\right), 131.3\left(m-\mathrm{C}_{\mathrm{Ar}}\right), 130.9\left(p-\mathrm{C}_{\mathrm{Ar}}\right), 129.8(o-$ $\left.\mathrm{C}_{\mathrm{Ar}}\right), 128.3\left(i-\mathrm{C}_{\mathrm{Ar}}\right), 126.6\left(\mathrm{C}_{\mathrm{Py}}\right), 41.8\left(\mathrm{NCH}_{3}\right), 37.5\left(\mathrm{NCH}_{3}\right)$. Anal. Calcd for $\mathrm{C}_{15} \mathrm{H}_{17} \mathrm{Cl}_{3} \mathrm{~N}_{4} \mathrm{Pd}$ (466.10): C, 38.65; H, 3.68; N, 12.02. Found: C, 38.16; H, 3.49; N, 11.64 .

Complex 3b. Reaction of $\mathbf{2 b}(500 \mathrm{mg}, 0.59 \mathrm{mmol})$ and $\mathrm{PdCl}_{2}(217 \mathrm{mg}, 1.23 \mathrm{mmol})$ according to the general procedure afforded $\mathbf{3 b}$ as a yellow solid $(226 \mathrm{mg}, 40 \%) .{ }^{1} \mathrm{H}$ NMR $\left(\mathrm{CDCl}_{3} 500 \mathrm{MHz}\right): \delta 9.00\left(\mathrm{~d},{ }^{4} J_{\mathrm{HH}}=2.2 \mathrm{~Hz}, 1 \mathrm{H}, \mathrm{H}_{\mathrm{Py}}\right), 8.89\left(\mathrm{dd},{ }^{3} J_{\mathrm{HH}}=5.5 \mathrm{~Hz}\right.$, $\left.{ }^{4} J_{\mathrm{HH}}=1.2 \mathrm{~Hz}, 1 \mathrm{H}, \mathrm{H}_{\mathrm{Py}}\right), 7.93\left(\mathrm{dd},{ }^{3} J_{\mathrm{HH}}=8.1 \mathrm{~Hz},{ }^{4} J_{\mathrm{HH}}=1.4 \mathrm{~Hz}, 2 \mathrm{H}, \mathrm{H}_{\mathrm{Ar}}\right), 7.72(\mathrm{ddd}$, $\left.{ }^{3} J_{\mathrm{HH}}=8.2 \mathrm{~Hz},{ }^{4} J_{\mathrm{HH}}=2.2 \mathrm{~Hz},{ }^{4} J_{\mathrm{HH}}=1.2 \mathrm{~Hz}, 1 \mathrm{H}, \mathrm{H}_{\mathrm{Py}}\right), 7.56\left(\mathrm{~m}, 3 \mathrm{H}, \mathrm{H}_{\mathrm{Ar}}\right), 7.28\left(\mathrm{ddd},{ }^{3} J_{\mathrm{HH}}\right.$ $\left.=8.2 \mathrm{~Hz},{ }^{3} J_{\mathrm{HH}}=5.5 \mathrm{~Hz},{ }^{5} J_{\mathrm{HH}}=0.4 \mathrm{~Hz}, 1 \mathrm{H}, \mathrm{H}_{\mathrm{Py}}\right), 5.03\left(\mathrm{q},{ }^{3} J_{\mathrm{HH}}=7.3 \mathrm{~Hz}, 2 \mathrm{H}, \mathrm{NCH}_{2} \mathrm{Me}\right)$ $3.99\left(\mathrm{~s}, 3 \mathrm{H}, \mathrm{NCH}_{3}\right), 1.86\left(\mathrm{t},{ }^{3} \mathrm{~J}_{\mathrm{HH}}=7.3 \mathrm{~Hz}, 3 \mathrm{H}, \mathrm{NCH}_{2} \mathrm{CH}_{3}\right) .{ }^{13} \mathrm{C}\left\{{ }^{1} \mathrm{H}\right\} \mathrm{NMR}\left(\mathrm{CDCl}_{3}, 125\right.$ $\mathrm{MHz}): \delta 150.5\left(\mathrm{C}_{\mathrm{Py}}\right), 149.5\left(\mathrm{C}_{\mathrm{Py}}\right), 143.8\left(\mathrm{C}_{\mathrm{trz}}-\mathrm{Ph}\right), 138.0\left(\mathrm{C}_{\mathrm{Py}}\right), 136.6\left(\mathrm{C}_{\mathrm{trz}}-\mathrm{Pd}\right), 133.0$ $\left(\mathrm{C}_{\mathrm{Py}}\right), 131.3\left(m-\mathrm{C}_{\mathrm{Ar}}\right), 130.9\left(p-\mathrm{C}_{\mathrm{Ar}}\right), 129.1\left(o-\mathrm{C}_{\mathrm{Ar}}\right), 126.7\left(i-\mathrm{C}_{\mathrm{Ar}}\right), 124.7\left(\mathrm{C}_{\mathrm{Py}}\right), 50.6$ $\left(\mathrm{NCH}_{2} \mathrm{Me}\right), 37.6\left(\mathrm{NCH}_{3}\right), 15.4\left(\mathrm{NCH}_{2} \mathrm{CH}_{3}\right)$. Anal. Calcd for $\mathrm{C}_{16} \mathrm{H}_{19} \mathrm{Cl}_{3} \mathrm{~N}_{4} \mathrm{Pd}(480.13)$ : C, 40.03; H, 3.99; N, 11.67. Found: C, 40.25.16; H, 3.91; N, 11.54 .

Complex 3c. According to the general procedure, a mixture of $\mathrm{PdCl}_{2}(276 \mathrm{mg}, 1.56$ $\mathrm{mmol})$ and $2 \mathrm{c}(670 \mathrm{mg}, 0.78 \mathrm{mmol})$ afforded $3 \mathrm{c}$ as a yellow powder $(400 \mathrm{mg}, 53 \%) .{ }^{1} \mathrm{H}$ NMR $\left(\mathrm{CDCl}_{3} 500 \mathrm{MHz}\right): \delta 9.10\left(\mathrm{~d},{ }^{4} J_{\mathrm{HH}}=2.0 \mathrm{~Hz}, 1 \mathrm{H}, \mathrm{H}_{\mathrm{Py}}\right), 8.98\left(\mathrm{dd},{ }^{3} J_{\mathrm{HH}}=5.4 \mathrm{~Hz}\right.$, $\left.{ }^{4} J_{\mathrm{HH}}=1.2 \mathrm{~Hz}, 1 \mathrm{H}, \mathrm{H}_{\mathrm{Py}}\right), 7.75\left(\mathrm{ddd},{ }^{3} J_{\mathrm{HH}}=8.1 \mathrm{~Hz},{ }^{4} J_{\mathrm{HH}}=2.0 \mathrm{~Hz},{ }^{4} J_{\mathrm{HH}}=1.2 \mathrm{~Hz}, 1 \mathrm{H}\right.$, $\left.\mathrm{H}_{\mathrm{Py}}\right), 7.31\left(\mathrm{ddd},{ }^{3} J_{\mathrm{HH}}=8.1 \mathrm{~Hz},{ }^{3} J_{\mathrm{HH}}=5.4 \mathrm{~Hz},{ }^{5} J_{\mathrm{HH}}=0.4 \mathrm{~Hz}, 1 \mathrm{H}, \mathrm{H}_{\mathrm{Py}}\right), 4.82(\mathrm{~m}, 2 \mathrm{H}$, $\mathrm{NCH}_{2}$ ), $3.95\left(\mathrm{~s}, 3 \mathrm{H}, \mathrm{NCH}_{3}\right), 3.04\left(\mathrm{t},{ }^{3} J_{\mathrm{HH}}=7.8 \mathrm{~Hz}, 2 \mathrm{H}, \mathrm{C}_{\mathrm{trz}}-\mathrm{CH}_{2}\right), 2.27$ (quint, ${ }^{3} J_{\mathrm{HH}}=$ $7.5 \mathrm{~Hz}, 2 \mathrm{H}, \mathrm{NCH}_{2} \mathrm{CH}_{2}$ ), 2.00 (quint, $\left.{ }^{3} J_{\mathrm{HH}}=7.8 \mathrm{~Hz}, 2 \mathrm{H}, \mathrm{C}_{\mathrm{trz}}-\mathrm{CH}_{2} \mathrm{CH}_{2}\right) 1.50(\mathrm{~m}, 4 \mathrm{H}$, $\left.\mathrm{NCH}_{2} \mathrm{CH}_{2} \mathrm{CH}_{2}+\mathrm{C}_{\mathrm{trz}}-\mathrm{CH}_{2} \mathrm{CH}_{2} \mathrm{CH}_{2}\right), 1.03,1.02\left(2 \times \mathrm{t},{ }^{3} J_{\mathrm{HH}}=7.3 \mathrm{~Hz}, 3 \mathrm{H}\right.$, $\left.\mathrm{NCH}_{2} \mathrm{CH}_{2} \mathrm{CH}_{2} \mathrm{CH}_{3}+\mathrm{C}_{\mathrm{trz}}-\mathrm{CH}_{2} \mathrm{CH}_{2} \mathrm{CH}_{2} \mathrm{CH}_{3}\right) .{ }^{13} \mathrm{C}\left\{{ }^{1} \mathrm{H}\right\} \mathrm{NMR}\left(\mathrm{CDCl}_{3}, 125 \mathrm{MHz}\right): \delta 150.6$ $\left(\mathrm{C}_{\mathrm{Py}}\right), 149.5\left(\mathrm{C}_{\mathrm{Py}}\right), 144.2\left(\mathrm{C}_{\mathrm{trz}}-\mathrm{Bu}\right), 138.0,134.9,132.8\left(3 \times \mathrm{C}_{\mathrm{Py}}\right), 129.2\left(\mathrm{C}_{\mathrm{trz}} \mathrm{Pd}\right), 54.6$ $\left(\mathrm{NCH}_{2}\right), 36.3\left(\mathrm{NCH}_{3}\right), 32.0\left(\mathrm{NCH}_{2} \mathrm{CH}_{2}\right), 31.4\left(\mathrm{C}_{\mathrm{trz}}-\mathrm{CH}_{2}\right), 25.0\left(\mathrm{C}_{\mathrm{trz}}-\mathrm{CH}_{2} \mathrm{CH}_{2}\right), 22.8$, $20.1\left(\mathrm{C}_{\mathrm{trz}}-\mathrm{CH}_{2} \mathrm{CH}_{2} \mathrm{CH}_{2}+\mathrm{NCH}_{2} \mathrm{CH}_{2} \mathrm{CH}_{2}\right)$, 14.0, $13.8\left(\mathrm{C}_{\mathrm{trz}}-\mathrm{CH}_{2} \mathrm{CH}_{2} \mathrm{CH}_{2} \mathrm{CH}_{3}+\right.$ $\mathrm{NCH}_{2} \mathrm{CH}_{2} \mathrm{CH}_{2} \mathrm{CH}_{3}$ ). Anal. Calcd for $\mathrm{C}_{16} \mathrm{H}_{25} \mathrm{Cl}_{3} \mathrm{~N}_{4} \mathrm{Pd}$ (480.13): C, 39.53; H, 5.18; N, 11.52. Found: C, 39.46.16; H, 5.09; N, 11.36.

Complex 3d. The title product was obtained according to the general procedure from $\mathrm{PdCl}_{2}(338 \mathrm{mg}, 1.90 \mathrm{mmol})$ and complex $2 \mathrm{~d}(975 \mathrm{mg}, 0.95 \mathrm{mmol})$ as a light yellow 
powder (184 mg, 18\%). ${ }^{1} \mathrm{H}$ NMR $\left(\mathrm{CDCl}_{3} 500 \mathrm{MHz}\right): \delta 8.80\left(\mathrm{~d},{ }^{4} J_{\mathrm{HH}}=2.2 \mathrm{~Hz}, 1 \mathrm{H}, \mathrm{H}_{\mathrm{Py}}\right)$, $8.68\left(\mathrm{dd},{ }^{3} J_{\mathrm{HH}}=5.5 \mathrm{~Hz},{ }^{3} J_{\mathrm{HH}}=1.1 \mathrm{~Hz}, 1 \mathrm{H}, \mathrm{H}_{\mathrm{Py}}\right), 8.11\left(\mathrm{~d},{ }^{3} J_{\mathrm{HH}}=7.0 \mathrm{~Hz}, 2 \mathrm{H}, \mathrm{H}_{\mathrm{Ar}}\right), 7.59$ $\left(\mathrm{m}, 3 \mathrm{H}, \mathrm{H}_{\mathrm{Ar}}\right), 7.56\left(\mathrm{~m}, 1 \mathrm{H}, \mathrm{H}_{\mathrm{Py}}\right), 7.11\left(\mathrm{~m}, 1 \mathrm{H}, \mathrm{H}_{\mathrm{Py}}\right), 7.06\left(\mathrm{~m}, 2 \mathrm{H}, \mathrm{H}_{\mathrm{Mes}}\right), 4.13(\mathrm{~s}, 3 \mathrm{H}$, $\left.\mathrm{NCH}_{3}\right), 2.39\left(\mathrm{~s}, 3 \mathrm{H}, \mathrm{ArCH}_{3}\right), 2.30\left(\mathrm{~s}, 6 \mathrm{H}, \mathrm{ArCH}_{3}\right) .{ }^{13} \mathrm{C}\left\{{ }^{1} \mathrm{H}\right\} \mathrm{NMR}\left(\mathrm{CDCl}_{3}, 125 \mathrm{MHz}\right): \delta$ $150.6\left(\mathrm{C}_{\mathrm{Py}}\right), 149.6\left(\mathrm{C}_{\mathrm{Py}}\right), 144.3\left(\mathrm{C}_{\mathrm{trz}}-\mathrm{Mes}\right), 140.6\left(\mathrm{C}_{\mathrm{Ar}}\right), 140.4\left(\mathrm{C}_{\mathrm{Ar}}\right), 137.7\left(\mathrm{C}_{\mathrm{Py}}\right), 136.1$ $\left(\mathrm{C}_{\mathrm{Py}}\right), 135.3\left(\mathrm{C}_{\mathrm{Ar}}\right), 132.3\left(\mathrm{C}_{\mathrm{trz}}-\mathrm{Pd}\right), 130.8\left(\mathrm{C}_{\mathrm{Ar}}\right), 130.4\left(\mathrm{C}_{\mathrm{Ar}}\right), 129.5\left(\mathrm{C}_{\mathrm{Ar}}\right), 129.1\left(\mathrm{C}_{\mathrm{Ar}}\right)$, 127.10 $\left(\mathrm{C}_{\mathrm{Py}}\right), 124.6\left(\mathrm{C}_{\mathrm{Ar}}\right), 37.9\left(\mathrm{NCH}_{3}\right), 21.5\left(\mathrm{Ar}-\mathrm{CH}_{3}\right), 19.0\left(\mathrm{Ar}-\mathrm{CH}_{3}\right)$. Anal. Calcd for $\mathrm{C}_{23} \mathrm{H}_{23} \mathrm{Cl}_{3} \mathrm{~N}_{4} \mathrm{Pd}(568.23) \times \mathrm{H}_{2} \mathrm{O}: \mathrm{C}, 47.12 ; \mathrm{H}, 4.30 ; \mathrm{N}, 9.56$. Found: C, 46.96; H, 4.21; N, 9.10 .

Complex 3e. Reaction of complex $2 \mathbf{e}(200 \mathrm{mg}, 0.18 \mathrm{mmol})$ and $\mathrm{PdCl}_{2}(64 \mathrm{mg}, 0.36$ $\mathrm{mmol})$ according to the general procedure yielded $3 \mathbf{e}$ as a yellow powder $(125 \mathrm{mg}$, $57 \%)$. ${ }^{1} \mathrm{H}$ NMR $\left(\mathrm{CDCl}_{3} 500 \mathrm{MHz}\right): \delta 8.75\left(\mathrm{~d},{ }^{4} J_{\mathrm{HH}}=2.2 \mathrm{~Hz}, 1 \mathrm{H}, \mathrm{H}_{\mathrm{Py}}\right), 8.65\left(\mathrm{dd},{ }^{3} J_{\mathrm{HH}}=\right.$ $\left.5.5 \mathrm{~Hz},{ }^{4} J_{\mathrm{HH}}=1.1 \mathrm{~Hz}, 1 \mathrm{H}, \mathrm{H}_{\mathrm{Py}}\right), 7.56\left(\mathrm{ddd},{ }^{3} J_{\mathrm{HH}}=8.1 \mathrm{~Hz},{ }^{4} J_{\mathrm{HH}}=2.2 \mathrm{~Hz},{ }^{4} J_{\mathrm{HH}}=1.1 \mathrm{~Hz}\right.$ $\left.1 \mathrm{H}, \mathrm{H}_{\mathrm{Py}}\right), 7.08\left(\mathrm{~m}, 1 \mathrm{H}, \mathrm{H}_{\mathrm{Py}}\right), 7.07\left(\mathrm{~s}, 2 \mathrm{H}, \mathrm{H}_{\mathrm{Mes}}\right), 7.05\left(\mathrm{~s}, 2 \mathrm{H}, \mathrm{H}_{\mathrm{Mes}}\right), 3.82\left(\mathrm{~s}, 3 \mathrm{H}, \mathrm{NCH}_{3}\right)$ 2.39, $2.38\left(2 \times \mathrm{s}, 3 \mathrm{H}, \mathrm{ArCH}_{3}\right), 2.32\left(\mathrm{~s}, 12 \mathrm{H}, \mathrm{ArCH}_{3}\right) .{ }^{13} \mathrm{C}\left\{{ }^{1} \mathrm{H}\right\} \mathrm{NMR}\left(\mathrm{CDCl}_{3}, 125\right.$ $\mathrm{MHz})$ : $\delta 150.7\left(\mathrm{C}_{\mathrm{Py}}\right), 149.8\left(\mathrm{C}_{\mathrm{Py}}\right), 143.6\left(\mathrm{C}_{\mathrm{trz}}-\mathrm{Mes}\right), 140.8\left(\mathrm{C}_{\mathrm{Ar}}\right), 140.6\left(\mathrm{C}_{\mathrm{Ar}}\right), 140.5\left(\mathrm{C}_{\mathrm{Ar}}\right)$, $139.5\left(\mathrm{C}_{\mathrm{Ar}}\right), 137.5\left(\mathrm{C}_{\mathrm{Py}}\right), 136.1\left(\mathrm{C}_{\mathrm{Py}}\right), 135.6\left(\mathrm{C}_{\mathrm{Ar}}\right), 132.1\left(\mathrm{C}_{\mathrm{trz}}-\mathrm{Pd}\right), 129.5\left(\mathrm{C}_{\mathrm{Ar}}\right), 129.1$ $\left(\mathrm{C}_{\mathrm{Ar}}\right), 124.4\left(\mathrm{C}_{\mathrm{Py}}\right), 122.9\left(\mathrm{C}_{\mathrm{Ar}}\right), 36.6\left(\mathrm{NCH}_{3}\right), 21.6\left(\mathrm{Ar}-\mathrm{CH}_{3}\right), 21.5\left(\mathrm{Ar}-\mathrm{CH}_{3}\right), 21.2(\mathrm{Ar}-$ $\left.\mathrm{CH}_{3}\right), 19.0\left(\mathrm{Ar}-\mathrm{CH}_{3}\right)$. Anal. Calcd for $\mathrm{C}_{26} \mathrm{H}_{29} \mathrm{Cl}_{3} \mathrm{~N}_{4} \mathrm{Pd}(610.30) \times \mathrm{H}_{2} \mathrm{O}: \mathrm{C}, 49.70 ; \mathrm{H}$, $4.97 ; \mathrm{N}, 8.92$. Found: C, 50.12; H, 4.61; N, 8.85

General procedures for Suzuki-Miyaura Cross Coupling. Phenyllboronic acid (147 $\mathrm{mg}, 1.2 \mathrm{mmol})$, base (1.5 mmol), 3-bromoanisole (127 $\mu \mathrm{L}, 1.0 \mathrm{mmol})$, and 2-propanol $(3.0 \mathrm{~mL})$ were added to a Schlenk tube charged with complex $3(0.5 \mathrm{~mol} \%$ or $1.0 \mathrm{~mol}$ $\%$ ) and a magnetic stirring bar. The Schlenk tube was placed in an oil bath pre-heated to $50{ }^{\circ} \mathrm{C}$ and stirred for the time indicated. The mixture was quenched with water, extracted with $\mathrm{CH}_{2} \mathrm{Cl}_{2}$, dried over $\mathrm{MgSO}_{4}$, and filtered through a pad of Celite. The solvent was removed under reduced pressure and the residue was analysed by ${ }^{1} \mathrm{H}$ NMR spectroscopy. Chemical shifts of the starting materials and products were compared with data reported previously. ${ }^{[39]}$

ESI-MS analyses. Complex $3(1 \mathrm{mg})$ was dissolved in $i \mathrm{PrOH}(3 \mathrm{~mL})$ at $50{ }^{\circ} \mathrm{C}$ and phenylboronic acid $(7 \mathrm{mg}), \mathrm{Bu}_{4} \mathrm{NF}(50 \mu \mathrm{L})$ and 3-bromoanisole $(7 \mathrm{mg})$ were added. MS spectra were recorded after 5, 20, and $35 \mathrm{~min}$ for samples $(10 \mu \mathrm{L})$ diluted with $i \mathrm{PrOH}$ $(1.5 \mathrm{~mL})$ on an Apex-Qe Ultra $7 \mathrm{~T}$ instrument (Bruker Daltonics, Germany) equipped with an ESI source. The potential between the spray needle and the orifice was set to $4.5 \mathrm{kV}$, the source accumulation time was $0.5 \mathrm{~s}$ and the ion accumulation time $0.5 \mathrm{~s}$.

Transmission electron microscopy. Complex $3(1 \mathrm{mg})$, phenylboronic acid $(7 \mathrm{mg})$ and 3 -bromoanisole $(7 \mathrm{mg})$ were placed in a test tube and subsequently $i \operatorname{PrOH}(3 \mathrm{~mL})$ and $\mathrm{Bu}_{4} \mathrm{NF}(50 \mu \mathrm{L})$ were added. The tube was sealed with a plastic stopper and heated at $50{ }^{\circ} \mathrm{C}$ for 35 minutes with magnetic stirring. A droplet of the reaction mixture was placed on a carbon-coated microscope grid and dried for $40 \mathrm{~min}$. TEM measurements were carried out using a FEI Tecnai $\mathrm{G}^{2} 20$ X-TWIN electron microscope (TEM) operating at $200 \mathrm{kV}$

Crystallographic details. Crystal data for complexes $\mathbf{3 b}$, 3c, and $\mathbf{3 d}$ were collected using an Agilent Technologies SuperNova A diffractometer fitted with an Atlas detector using monochromated $\mathrm{Mo}-\mathrm{K}_{\alpha}$ radiation $(0.71073 \AA)$. An at least complete dataset was collected, assuming that the Friedel pairs are not equivalent. An analytical numeric absorption correction was performed. ${ }^{[40]}$ The structures were solved by direct methods using SHELXS-97 and refined by full matrix least-squares on $\mathrm{F}^{2}$ for all data using SHELXL-97. ${ }^{[41]}$ Hydrogen atoms were added at calculated positions and refined using a riding model. Anisotropic thermal displacement parameters were used for all nonhydrogen atoms. Further crystallographic details are compiled in the supporting information (Tables S1-S3). CCDC 855567-855569 contain the supplementary crystallographic data for this paper. These data can be obtained free of charge from the Cambridge Crystallographic Data Centre via www.ccdc.cam.ac.uk/data_request/cif.

\section{Acknowledgements}

We thank Dr Ewa Mieczyńska and Mr Marek Jon (Faculty of Chemistry, University of Wrocław) for experimental assistance. Financial support from Science Foundation Ireland, the European Research Council (ERC Starting Grant), the Polish Ministry of Science and Higher Education (N164/COST/2008), and COST D40 is gratefully acknowledged.

[1] (a) Metal-Catalyzed Cross-Coupling Reactions (Eds.: A. de Meijere, F Diederich), Wiley-VCH, Weinheim, Germany, 2004. (b) Modern Arylation Methods (Ed. L. Ackermann), Wiley-VCH, Weinheim, Germany, 2009. (c) Palladacycles (Eds.: J. Dupont, M. Pfeffer), Wiley-VCH, Weinheim, Germany, 2010. (d) A. Suzuki, Angew. Chem. Int. Ed. 2011, 50, 6722-6737. (e) E. Negishi, Angew. Chem. Int. Ed. 2011, 50, 6738-6764. (f) I. P. Beletskaya, A. V. Cheprakov, Chem. Rev. 2000, 100, 3009-3066 (g) J. F. Hartwig, Nature 2008,
455, 314-319. (h) J.-P. Corbet, G. Mignani, Chem. Rev. 2006, 106, 2651-2710. (i) J. Magano, J. R. Dunetz, Chem. Rev. 2011, 111, 2177-2250.

[2] For examples, see: (a) D. Alberico, M. E. Scott, M. Lautens, Chem. Rev. 2007, 107, 174-238. (b) T. W. Lyons, M. S. Sanford, Chem. Rev. 2010, 110, 1147 1169. (c) X. Chen, K. M. Engle, D.-H. Wang, J.-Q. Yu, Angew. Chem. Int. Ed. 2009, 48, 5094-5115.

[3] (a) N. Miyaura, A. Suzuki, Chem. Rev. 1995, 95, 2457-2483. (b) M. Portnoy, D. Milstein, Organometallics 1993, 12, 1665-1673.

[4] M. Beller, H. Fischer, W. A. Herrmann, K. Öfele, C. Brossmer, Angew. Chem. Int. Ed. Engl. 1995, 34, 1848-1849.

[5] A. F. Littke, G. C. Fu, Angew. Chem. Int. Ed. 1998, 37, 3387-3388.

[6] D. W. Old, J. P. Wolfe, S. L. Buchwald, J. Am. Chem. Soc. 1998, 120, 9722 9723.

[7] C. Zhang, J. Huang, M. L. Trudell, S. P. Nolan, J. Org. Chem. 1999, 64, 38043805 .

[8] (a) M. G. Organ, S. Avola, I. Dubovyk, N. Hadei, E. A. B. Kantchev, C. J. O'Brien, C. Valente, Chem. Eur. J. 2006, 12, 4749-4755. (b) C. J. O’Brien, E. A B. Kantchev, C. Valente, N. Hadei, G. A. Chass, A. Lough, A. C. Hopkinson, M. G. Organ, Chem. Eur. J. 2006, 12, 4743-4748. (c) E. A. B. Kantchev, C. J. O'Brien, M. G. Organ, Angew. Chem. Int. Ed. 2007, 46, 2768-2813. For a related concept, see: (d) O. Navarro, N. Marion, J. Mei, S. P. Nolan, Chem. Eur. J. 2006, 12, 5142-5148. (e) M.-T. Chen, D. A. Vicic, M. L. Turner, O. Navarro, Organometallics 2011, 30, 5052-5056.

[9] (a) N-Heterocyclic Carbenes in Synthesis (Ed.: S. P. Nolan), Wiley-VCH, Weinheim, Germany, 2006. (b) Heterocyclic Carbenes in Transition Metal Catalysis and Organocatalysis (Ed.: C. S. J. Cazin), Springer, Berlin, Germany, 2010. (c) N-heterocyclic carbenes: From Laboratory Curiosities to Efficient Synthetic Tools, (Ed: S. Diez-Gonzalez), RSC, Cambridge, UK, 2011. (d) D Bourissou, O. Guerret, F. P. Gabbai, G. Bertrand, Chem. Rev. 2000, 100, 39-91; (e) W. A. Herrmann, C. Köcher, Angew. Chem. Int. Ed. 2002, 41, 1290. (f) F. E. Hahn, M. C. Jahnke, Angew. Chem. Int. Ed. 2008, 47, 3122-3172. (g) A. J. Arduengo, G. Bertrand, Chem. Rev. 2009, 109, 3209-3210 (thematic issue).

[10] (a) P. L. Arnold, J. Pearson, Coord. Chem. Rev. 2007, 251, 596-609. (b) M. Albrecht, Chem. Commun. 2008, 3601-3610. (c) O. Schuster, L. Yang, M. Albrecht, H. G. Raubenheimer, Chem. Rev. 2009, 109, 3445-3478. (d) M. Melami, M. Soleilhavoup, G. Bertrand, Angew. Chem. Int. Ed. 2010, 49, 8810 8849. (e) D. G. Gusev, Organometallics 2009, 28, 6458-6461. (f) Y. Han, H. V. Huynh, Dalton Trans. 2011, 40, 2141-2147. M. Iglesias, M. Albrecht, Dalton Trans. 2010, 39, 5213-5215.

[11] (a) A. Lawson, C. E. Searle, J. Chem. Soc. 1957, 1556-1561. (b) IUPAC. Compendium of Chemical Terminology, 2nd ed. (the "Gold Book"). Compiled by A. D. McNaught and A. Wilkinson. Blackwell Scientific Publications, Oxford (1997). XML.

[12] P. Mathew, A. Neels, M. Albrecht, J. Am. Chem. Soc. 2008, 130, 13534-13535.

[13] G. Guisado-Barrios, J. Bouffard, B. Donnadieu, G. Bertrand, Angew. Chem. Int Ed. 2010, 49, 4759-4762.

[14] (a) R. Lalrempuia, N. D. McDaniel, H. Müller-Bunz, S. Bernhard, M. Albrecht Angew. Chem. Int. Ed. 2010, 49, 9765-9768. (b) T. Nakamura, K. Ogata, S. Fukuzawa, Chem. Lett. 2010, 39, 920-922. (c) K. J. Kilpin, U. S. D. Paul, A.-L. Lee, J. D. Crowley, Chem. Commun. 2011, 47, 328-330. (d) T. Nakamura, T. Terashima, K. Ogata, S. Fukuzawa, Org. Lett. 2011, 13, 620-623. (e) A. Poulain, D. Canseco-Gonzalez, R. Hynes-Roche, H. Müller-Bunz, O. Schuster, H. Stoeckli-Evans, A. Neels, M. Albrecht, Organometallics, 2011, 30, 1021-1029. (f) A. Prades, E. Peris, M. Albrecht, Organometallics 2011, 30, 1162-1167. (g) R. Saravanakumar, V. Ramkumar, S. Sankararaman, Organometallics 2011, 30 , 1689-1694. (h) J. Bouffard, B. K. Keitz, R. Tonner, G. Guisado-Barrios, G. Frenking, R. H. Grubbs, G. Bertrand, Organometallics 2011, 30, 2617-2627. (i) L. Bernet, R. Lalrempuia, W. Ghattas, H. Mueller-Bunz, L. Vigara, A. Llobet, M. Albrecht, Chem. Commun. 2011, 47, 8058-8060. (j) J. D. Crowley, A.-L. Lee, K. J. Kilpin, Aust. J. Chem. 2011, 64, 1118-1132.

[15] (a) R. Huisgen, Angew. Chem. Int. Ed. 1963, 2, 565-598. (b) H. Kolb, M. G. Finn, K. B. Sharpless, Angew. Chem. Int. Ed. 2001, 40, 2004-2021. (c) M. Meldal, C. W. Tornoe, Chem. Rev. 2008, 108, 2952-3015. (d) M. G. Finn, V. V. Fokin, Chem. Soc. Rev. 2010, 39, 1231-1232 (themed issue).

[16] Similar observations have recently been reported in ruthenium-catalyzed olefin metathesis: B. K. Keitz, J. Bouffard, G. Bertrand, R. H. Grubbs, J. Am. Chem. Soc. 2011, 133, 8498-8501.

[17] See the supporting information for details. 
[18] The pertinent ${ }^{13} \mathrm{C}$ NMR chemica shifts for C-Pd are 138.0 (3a), 136.6 (3b), 129.2 (3c), 132.3 (3d), and 132.1 (3e)

[19] A. Poulain, M. Iglesias, M. Albrecht, Curr. Org. Chem. 2011, 15, 3325-3336.

[20] Similar to $\mathbf{3 b}$, complexes $\mathbf{4}$ and $\mathbf{5}$ exhibit poor catalytic performance when DMA or dioxane was used as solvent. See the supporting information for a time conversion profile of $\mathbf{4}$ and 5 .

[21] H. Lebel, M. K. Janes, A. B. Charette, S. P. Nolan, J. Am. Chem. Soc. 2004, 126 , 5046-5047.

[22] (a) D. Bacciu, K. J. Cavell, I. A. Fallis, L.-I. Ooi, Angew. Chem. Int. Ed. 2005 44, 5282-5284. (b) M. Heckenroth, A. Neels, M. G. Garnier, P. Aebi, A. W. Ehlers, M. Albrecht, Chem. Eur. J. 2009, 15, 9375-9386.

[23] J. Nasielski, N. Hadei, G. Achonduh, E. A. Kantchev, C. J. O’Brien, M. G Organ, Chem. Eur. J. 2010, 16, 10844-10853.

[24] (a) A. F. Littke, G. C. Fu, Angew. Chem. Int. Ed. 2002, 41, 4176-4211. (b) R. B. Bedford, C. S. J. Cazin, D. Holder, Coord. Chem. Rev. 2004, 248, 2283-2321 Nanoparticles have been reported to catalyze aryl chloride conversion: (c) R. B. Bedford, M. E. Blake, C. P. Butts, D. Holder, Chem. Commun. 2003, 466-467 (d) N. E. Leadbeater, M. Marco, Org. Lett. 2002, 4, 2973-2976.

[25] I. Blaszczyk, A. Gniewek, A. M. Trzeciak, J. Organomet. Chem. 2011, 696, 3601-3607.

[26] a) D. R. Anton, R. H. Crabtree, Organometallics 1983, 2, 855-859. (b) G. M. Whitesides, M. Hackett, R. L. Brainard, J. P. P. M. Lavalleye, A. F. Sowinski, A N. Izumi, S. S. Moore, D. W. Brown, E. M. Staudt, Organometallics 1985, 4 , 1819-1830. (c) J. A. Widegren, R. G. Finke, J. Mol. Cat. A. 2003, 198, 317-341. (d) R. H. Crabtree, 2012, 112, in press. DOI: 10.1021/cr2002905. Mercury poisoning in palladium-catalyzed cross-coupling is not unambiguous, see: (e) $\mathrm{N}$. T. S. Phan, M. van der Sluys, C. W. Jones, Adv. Synth. Catal. 2006, 348, 609679.

[27] R. D. Lovert, J. M. Miller, J. E. Hutchision, ACS Nano 2011, 5, 8950-8957.

[28] I. P. Beletskaya, A. N. Kashin, I. A. Khotina, A. R. Khokhlov, Synlett 2008 , $1547-1552$.

[29] W. Zawartka, A. Gniewek, A. M. Trzeciak, J. J. Ziolkowski, J. Pernak, J. Mol. Catal. A: Chem. 2009, 304, 8-15.

[30] P. Lara, O. Rivada-Wheelaghan, S. Conejero, R. Poteau, K. Philippot, B. Chaudret, Angewe. Chem. Int. Ed. 2012, 51, in press. DOI 10.1002/anie.201106348.

[31] B. Liu, Q. Xia, W. Chen, Angew. Chem. Int. Ed. 2009, 48, 5513-5516.

[32] C. C. Cassol, A. P. Umpierre, G. Machado, S. I. Wolke, J. Dupont, J. Am. Chem Soc. 2005, 127, 3298-3299.

[33] A. Gniewek, A. M. Trzeciak, J. J. Ziolkowski, L. Kepinski, J. Wrzyszcz, W. Tylus, J. Catal. 2005, 229, 332-343.
[34] Heterogenization has been report to occur, though generally, the catalytic activity has been attributed to the nanoparticles themselves and not to redissolved molecular palladium species. See: (a) M. T. Reetz, J. G. de Vries, Chem. Commun. 2004, 1559-1563. (b) J. G. de Vries, Dalton Trans. 2006, 421 429. (c) D. Astruc, Inorg. Chem. 2007, 46, 1884-1894. (d) Y. Tsuji, T. Fujihara Inorg. Chem. 2007, 46, 1895-1902. (e) A. Gniewek, J. J. Ziolkowski, A. M. Trzeciak, M. Zawadzki, H. Grabowska, J. Wrzyszcz, J. Catal. 2008, 254, 121130. (f) Y.-H. Chen, H.-H. Hung, M. H. Huang, J. Am. Chem. Soc. 2009, 131, 9114-9121. (g) P. J. Ellis, I. J. S. Fairlamb, S. F. J. Hackett, K. Wilson, A. F. Lee, Angew. Chem. Int. Ed. 2010, 49, 1820-1824. (h) A. N. Kashin, I. P. Beletskaya, Russ. J. Org. Chem. 2011, 47, 475-479. For critical reviews, see also: (i) I. P. Beletskaya, A. V. Cheprakov, J. Organomet. Chem. 2004, 689, 4055-4082. (j) L. Yin, J. Liebscher, Chem. Rev. 2007, 107, 133-173.

[35] Metal leaching from solid supports has been demonstrated for the Heck reaction at high temperatures: (a) S. S. Pröckl, W. Kleist, M. A. Gruber, K. Köhler, Angew. Chem. Int. Ed. 2004, 43, 1881-1882. (b) S. S. Pröckl, W. Kleist, K. Köhler, Tetrahedron 2005, 61, 9855-9859. (c) J. M. Richardson, C. W. Jones, Adv. Synth. Catal. 2006, 348, 1207-1216. (d) I. Pryjomska-Ray, A. Gniewek, A. M. Trzeciak, J. J. Ziolkowski, W. Tylus, Top. Catal. 2006, 40, 173-184. (e) S. MacQuarrie, J. H. Horton, J. Barnes, K. McEleney, H.-P. Loock, C. M. Crudden, Angew. Chem. Int. Ed. 2008, 47, 3279-3282. (f) P.-P. Fang, A. Jutand, Z.-Q. Tian, C. Amatore, Angew. Chem. Int. Ed. 2011, 50, in press. DOI: 10.1002/anie.201103465. For a relevant example in palladium-catalyzed addition reactions, see: V. P. Ananikov, N. V. Orlov, I. P. Beletskaya, V. N. Khrustalev, M. Y. Antipin, T. V. Timofeeva, J. Am. Chem. Soc. 2007, 129, $7252-7253$.

[36] (a) M. Weck, C. W. Jones, Inorg. Chem. 2007, 46, 1865-1875. (b) K. Köhler, W. Kleist, S. S. Pröck1, Inorg. Chem. 2007, 46, 1876-1883.

[37] (a) G. Zassinovich, G. Mestroni, S. Gladiali, Chem. Rev. 1992, 92, 1051-1069. (b) D. Klomp, U. Hanefeld, J. A. Peters, in Handbook of Homogeneous Hydrogenation, vol. 2 (Eds.: J. G. de Vries, C. J. Elsevier), Wiley-VCH, Weinheim, Germany, 2007, 585-630. (c) S. Gladiali, E. Alberico, Chem. Soc. Rev. 2006, 35, 226-236. (d) J. S. M. Samec, J.-E. Bäckvall, P. G. Andersson, P. Brandt, Chem. Soc. Rev., 2006, 35, 237-248.

[38] (a) P. Appukkuttana, W. Dehaena, V. Fokin, M. Van der Eycken, Org Lett. 2004, 6, 4223-4225. (b) K. Barral D. A. Moorhouse, J. E. Moses, Org Lett. 2007, 9 , 1809-1811. (c) D. Kumar, V. B. Reddy, Synthesis 2010, 1687-1691.

[39] J. Jin, M. Min, J. X. Li, Synlett 2009, 2534-2538.

[40] Program CrysalisPro Version 1.171.34.36, Oxford Diffraction Limited, 2010.

[41] G. M. Sheldrick, Acta Cryst. 2008, A64, 112-122.

Received: ((will be filled in by the editorial staff))

Revised: ((will be filled in by the editorial staff)) Published online: ((will be filled in by the editorial staff)) 
PEPPSI Cross-Coupling

D. Canseco-Gonzalez, A. Gniewek, $M$. Szulmanowicz, H. Müller-Bunz, A. M. Trzeciak,* M. Albrecht*

PEPPSI-type palladium complexes containing basic 1,2,3-triazolylidene ligands and their role in SuzukiMiyaura catalysis

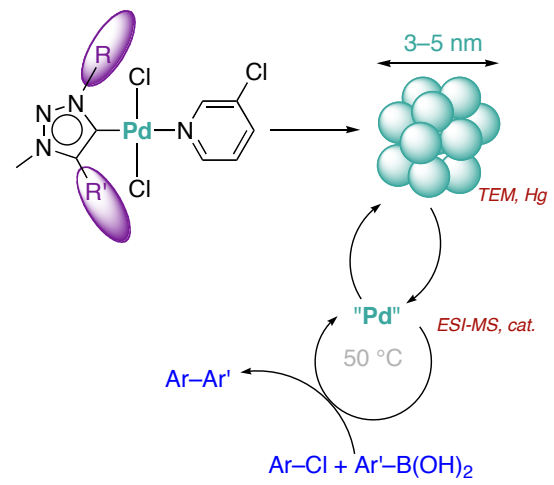

Triazolylidene palladium complexes comprising a easily removable ligand were synthesized and evaluated in aryl-aryl cross-coupling catalysis. Mechanistic investigations revealed an operationally homogeneous catalyst that originates from heterogenized nanoparticles as catalyst resting state. 
Supporting Information belonging to

PEPPSI-type palladium complexes containing basic 1,2,3-triazolylidene ligands and their role in Suzuki-Miyaura catalysis

Daniel Canseco-Gonzalez, ${ }^{a}$ Andrzej Gniewek, ${ }^{b}$ Michal Szulmanowicz, ${ }^{b}$ Helge Müller-Bunz, ${ }^{a}$ Anna Trzeciak,*, Martin Albrecht*a

\section{Content}

1. Experimental procedures for the new triazolium salts 1a and 1d .................................S2

2. Experimental procedures for the new silver triazolylidenes $\mathbf{2 a}, \mathbf{2 c}$, and $\mathbf{2 d} \ldots \ldots \ldots \ldots \ldots \ldots \ldots \ldots . . . \mathrm{S} 3$

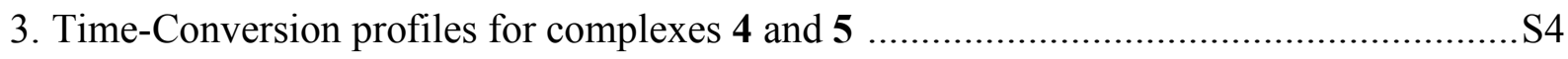

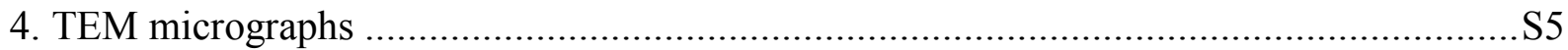

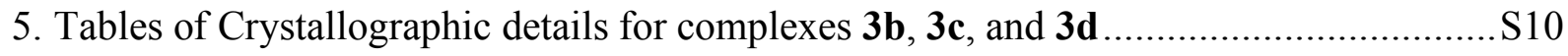

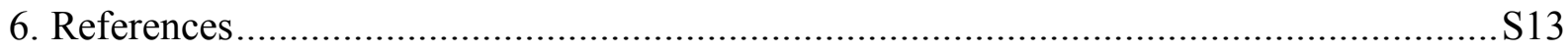




\section{Experimental procedures for the new triazolium salts 1a and 1d}

1,3-dimethyl-4-phenyl-1,2,3-triazolium iodide 1a. 1-methyl-4-phenyl-1,2,3-triazole ${ }^{[\mathrm{S} 1]} \quad(800$ $\mathrm{mg}, 5.0 \mathrm{mmol})$ and $\mathrm{MeI}(3.5 \mathrm{~g}, 25 \mathrm{mmol})$ in $\mathrm{MeCN}(20 \mathrm{~mL})$ were stirred under microwave irradiation at $90{ }^{\circ} \mathrm{C}$ for $5 \mathrm{~h}$. All volatiles were then removed in vacuo. The residue was washed with copious amounts of $\mathrm{Et}_{2} \mathrm{O}$ and dried in vacuo to afford the crude triazolium salt $\mathbf{1 a}$ as a white solid (1.0 g, 75\%). Microanalytically pure samples were obtained by recrystallization from hot acetone. ${ }^{1} \mathrm{H} \mathrm{NMR}\left(\mathrm{CDCl}_{3}, 500 \mathrm{MHz}\right): \delta 9.36\left(\mathrm{~s}, 1 \mathrm{H}, \mathrm{H}_{\mathrm{trz}}\right), 7.69\left(\mathrm{~m}, 2 \mathrm{H}, \mathrm{H}_{\mathrm{Ar}}\right), 7.52\left(\mathrm{~m}, 3 \mathrm{H}, \mathrm{H}_{\mathrm{Ar}}\right)$, $4.47\left(\mathrm{~s}, 3 \mathrm{H}, \mathrm{NCH}_{3}\right), 4.26\left(\mathrm{~s}, 3 \mathrm{H}, \mathrm{NCH}_{3}\right) .{ }^{13} \mathrm{C}\left\{{ }^{1} \mathrm{H}\right\} \mathrm{NMR}\left(\mathrm{CDCl}_{3}, 125 \mathrm{MHz}\right): \delta 142.9\left(\mathrm{C}_{\mathrm{trz}}-\mathrm{Ph}\right)$, $131.9\left(p-\mathrm{C}_{\mathrm{Ar}}\right), 130.5\left(m-\mathrm{C}_{\mathrm{Ar}}\right), 130.5\left(o-\mathrm{C}_{\mathrm{Ar}}\right), 129.7\left(\mathrm{C}_{\mathrm{trz}}-\mathrm{H}\right), 121.7\left(i-\mathrm{C}_{\mathrm{Ar}}\right) 41.3\left(\mathrm{NCH}_{3}\right), 39.3$ $\left(\mathrm{NCH}_{3}\right) . \mathrm{M} / \mathrm{z}: 174.4[\mathrm{M}-\mathrm{I}]^{+}$. Anal. Calcd for $\mathrm{C}_{10} \mathrm{H}_{12} \mathrm{IN}_{3}$ (301.13): C, 39.89; H, 4.02; N, 13.95 . Found: C, 39.82; H, 4.06; N, 13.92 .

1-mesityl-3-methyl-4-phenyl-1,2,3-triazolium iodide 1d. Reaction of 1-mesityl-4-phenyl1,2,3-triazole ${ }^{[\mathrm{S} 2]}(1.00 \mathrm{~g}, 3.8 \mathrm{mmol})$ and $\mathrm{CH}_{3} \mathrm{I}(5.4 \mathrm{~g}, 38 \mathrm{mmol})$ in $\mathrm{MeCN}(12 \mathrm{~mL})$ according to the procedure described for $\mathbf{1 a}$ gave $1 \mathbf{d}$ as a white solid $(1.40 \mathrm{~g}, 91 \%) .{ }^{1} \mathrm{H} \mathrm{NMR}\left(\mathrm{CDCl}_{3}, 500\right.$ MHz): $\delta 8.88\left(\mathrm{~s}, 1 \mathrm{H}, \mathrm{H}_{\mathrm{trz}}\right), 8.04\left(\mathrm{~d},{ }^{3} J_{\mathrm{HH}}=7.6 \mathrm{~Hz}, 2 \mathrm{H}, \mathrm{H}_{\mathrm{Ar}}\right), 7.58\left(\mathrm{~m}, 3 \mathrm{H}, \mathrm{H}_{\mathrm{Ar}}\right), 7.05\left(\mathrm{~s}, 2 \mathrm{H}, \mathrm{H}_{\mathrm{Mes}}\right)$, $4.58\left(\mathrm{~s}, 3 \mathrm{H}, \mathrm{NCH}_{3}\right), 2.37\left(\mathrm{~s}, 3 \mathrm{H}, \mathrm{ArCH}_{3}\right), 2.23\left(\mathrm{~s}, 6 \mathrm{H}, \mathrm{ArCH}_{3}\right) .{ }^{13} \mathrm{C}\left\{{ }^{1} \mathrm{H}\right\} \mathrm{NMR}\left(\mathrm{CDCl}_{3}, 125\right.$ $\mathrm{MHz}): \delta 144.4\left(\mathrm{C}_{\mathrm{trz}}-\mathrm{Mes}\right), 142.8,134.7,132.4,131.4,130.7\left(5 \times \mathrm{C}_{\mathrm{Ar} / \mathrm{Mes}}\right), 130.4\left(\mathrm{C}_{\mathrm{trz}}-\mathrm{H}\right), 130.2$ 129.9, $121.5\left(3 \times \mathrm{C}_{\mathrm{Ar} / \mathrm{Mes}}\right), 41.0\left(\mathrm{NCH}_{3}\right), 21.4\left(\mathrm{ArCH}_{3}\right), 18.8\left(\mathrm{ArCH}_{3}\right)$. Anal. Calcd for $\mathrm{C}_{18} \mathrm{H}_{20} \mathrm{IN}_{3}$ (405.28): C, 53.34; H, 4.97; N, 10.37. Found: C, 53.29; H, 4.94; N, 10.25 


\section{Experimental procedures for the new silver triazolylidenes $2 \mathrm{a}, 2 \mathrm{c}$, and $2 \mathrm{~d}$}

General procedure. To a solution of the triazolium salt 1 (1.0 eq) in $\mathrm{CH}_{2} \mathrm{Cl}_{2}$ was added $\mathrm{Ag}_{2} \mathrm{O}$ (0.5 eq). The mixture was stirred in the absence of light at room temperature for $2 \mathrm{~h}$ and filtered through Celite. The solvent was removed in vacuo at room temperature and the residue was washed with pentane $(3 \times 25 \mathrm{~mL})$ and dried in vacuo.

Complex 2a. According to the general procedure, a solution of $1 \mathbf{a}(300 \mathrm{mg}, 1.0 \mathrm{mmol})$ in $\mathrm{CH}_{2} \mathrm{Cl}_{2}$ $(30 \mathrm{~mL})$ was reacted with $\mathrm{Ag}_{2} \mathrm{O}(116 \mathrm{mg}, 0.49 \mathrm{mmol})$ to yield the silver carbene intermediate as a white solid (189 mg, 46\%). ${ }^{1} \mathrm{H}$ NMR (DMSO-D $\left.6,300 \mathrm{MHz}\right): \delta 7.71\left(\mathrm{~m}, 2 \mathrm{H}, \mathrm{H}_{\mathrm{Ar}}\right), 7.53(\mathrm{~m}, 3 \mathrm{H}$, $\left.\mathrm{H}_{\mathrm{Ar}}\right), 4.25\left(\mathrm{~s}, 3 \mathrm{H}, \mathrm{NCH}_{3}\right), 4.13\left(\mathrm{~s}, 3 \mathrm{H}, \mathrm{NCH}_{3}\right)$.

Complex 2c. Reaction of $1 c^{[\mathrm{S} 3]}(520 \mathrm{mg}, 1.6 \mathrm{mmol})$ and $\mathrm{Ag}_{2} \mathrm{O}(187 \mathrm{mg}, 0.80 \mathrm{mmol})$ in $\mathrm{CH}_{2} \mathrm{Cl}_{2}$ (30 $\mathrm{mL})$ according to the general procedure yielded $2 \mathrm{c}$ as a yellow oil $(692 \mathrm{mg}, 93 \%)$. The compound was used immediately as obtained for the next step, no ${ }^{1} \mathrm{H}$ NMR was recorded.

Complex 2d. Reaction of $\mathbf{1 d}(1012 \mathrm{mg}, 2.6 \mathrm{mmol})$ and $\mathrm{Ag}_{2} \mathrm{O}$ (290 mg, $\left.1.3 \mathrm{mmol}\right)$ in $\mathrm{CH}_{2} \mathrm{Cl}_{2}(30$ $\mathrm{mL}$ ) according to the general procedure gave $\mathbf{2 d}$ as a white solid (1018 $\mathrm{mg}, 77 \%)$. ${ }^{1} \mathrm{H}$ NMR (DMSO-D $6,300 \mathrm{MHz}): \delta 7.67-7.49\left(\mathrm{~m}, 5 \mathrm{H}, \mathrm{H}_{\mathrm{Ar}}\right), 7.07\left(\mathrm{~s}, 2 \mathrm{H}, \mathrm{H}_{\mathrm{Mes}}\right), 4.23\left(\mathrm{~s}, 3 \mathrm{H}, \mathrm{NCH}_{3}\right), 2.39$ (s, 3H, $\left.\mathrm{ArCH}_{3}\right), 1.86$ (s, 6H, $\mathrm{ArCH}_{3}$ ). 


\section{Time-Conversion profiles for complexes 4 and 5}

Time-conversion profile for the coupling of bromoanisole $(1.0 \mathrm{mmol})$ and phenylboronic acid (1.2 mmol) catalyzed by complex $4(0.5 \mathrm{~mol} \%$, blue diamonds) or 5 (red squares; $1 \mathrm{~mol} \%)$ with $\mathrm{Bu}_{4} \mathrm{NF}(1.5 \mathrm{mmol})$ in $i \operatorname{PrOH}(3 \mathrm{~mL})$ at $50{ }^{\circ} \mathrm{C}$.

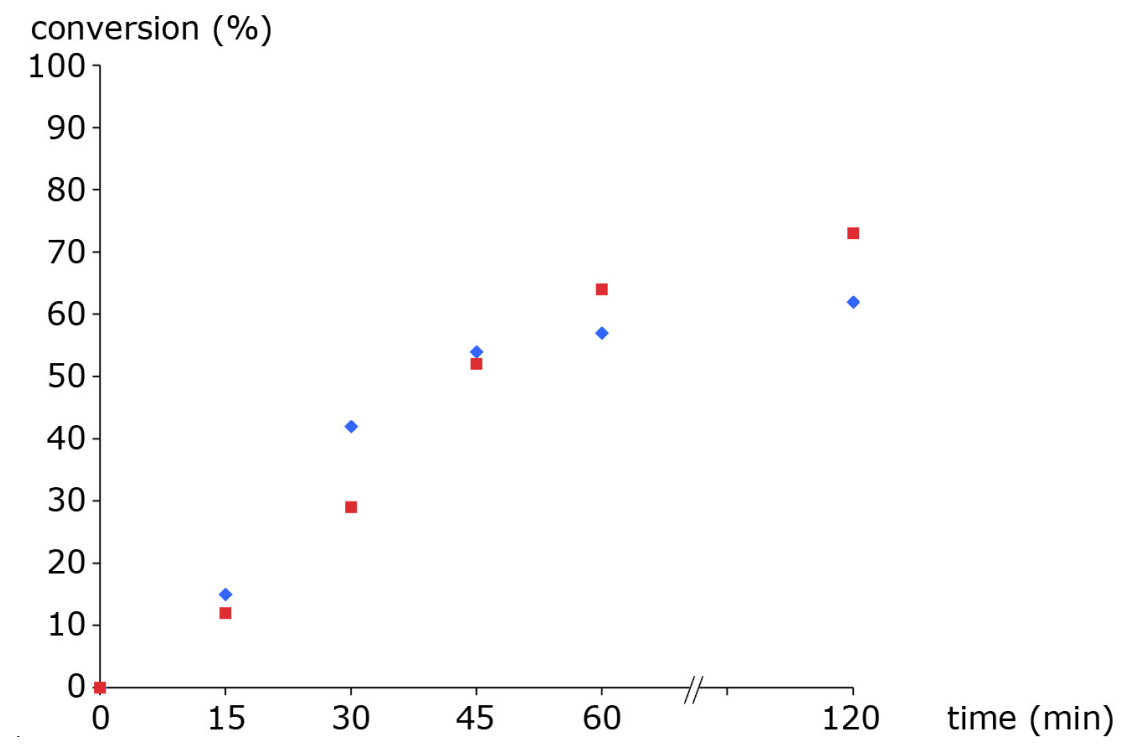




\section{TEM micrographs}
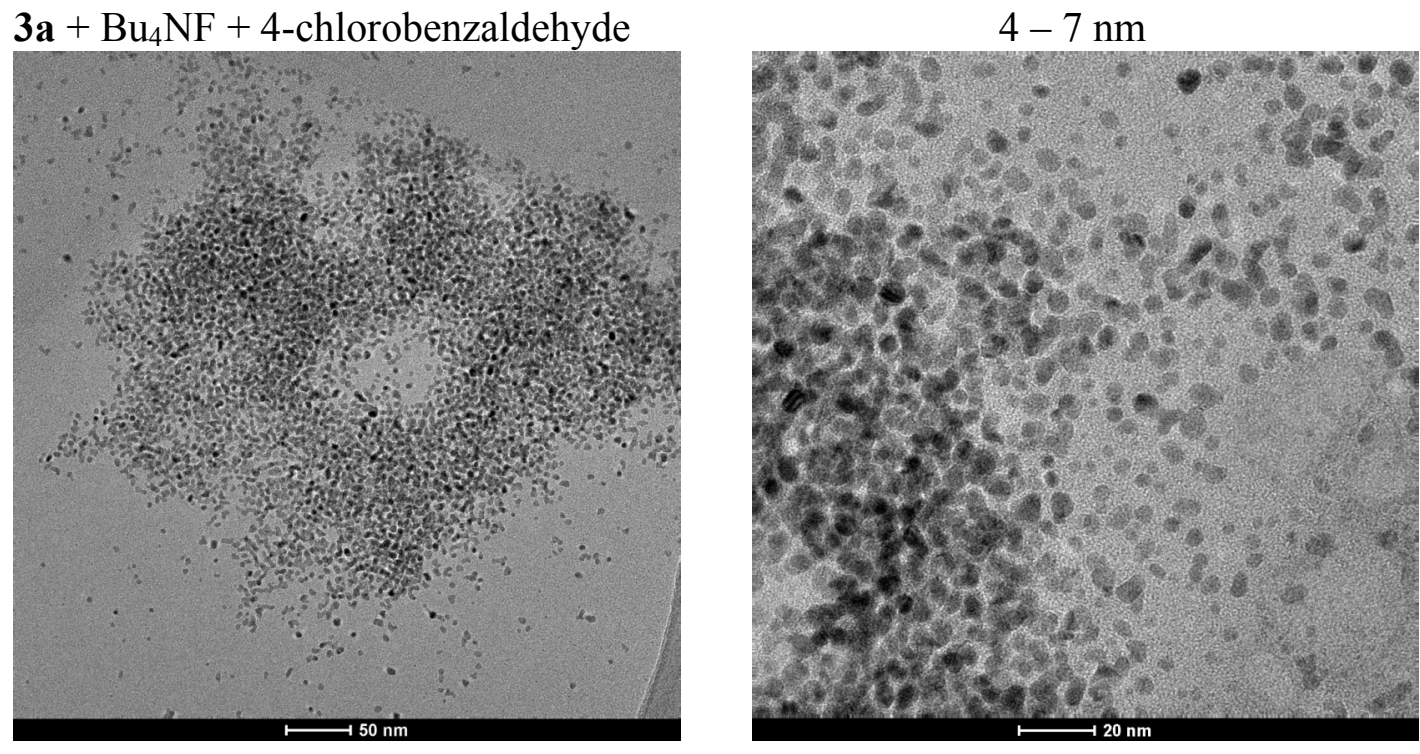

$\mathbf{3 a}+\mathrm{Bu}_{4} \mathrm{NF}+\mathrm{PhB}(\mathrm{OH})_{2}+4$-chlorobenzaldehyde $3-5 \mathrm{~nm}$
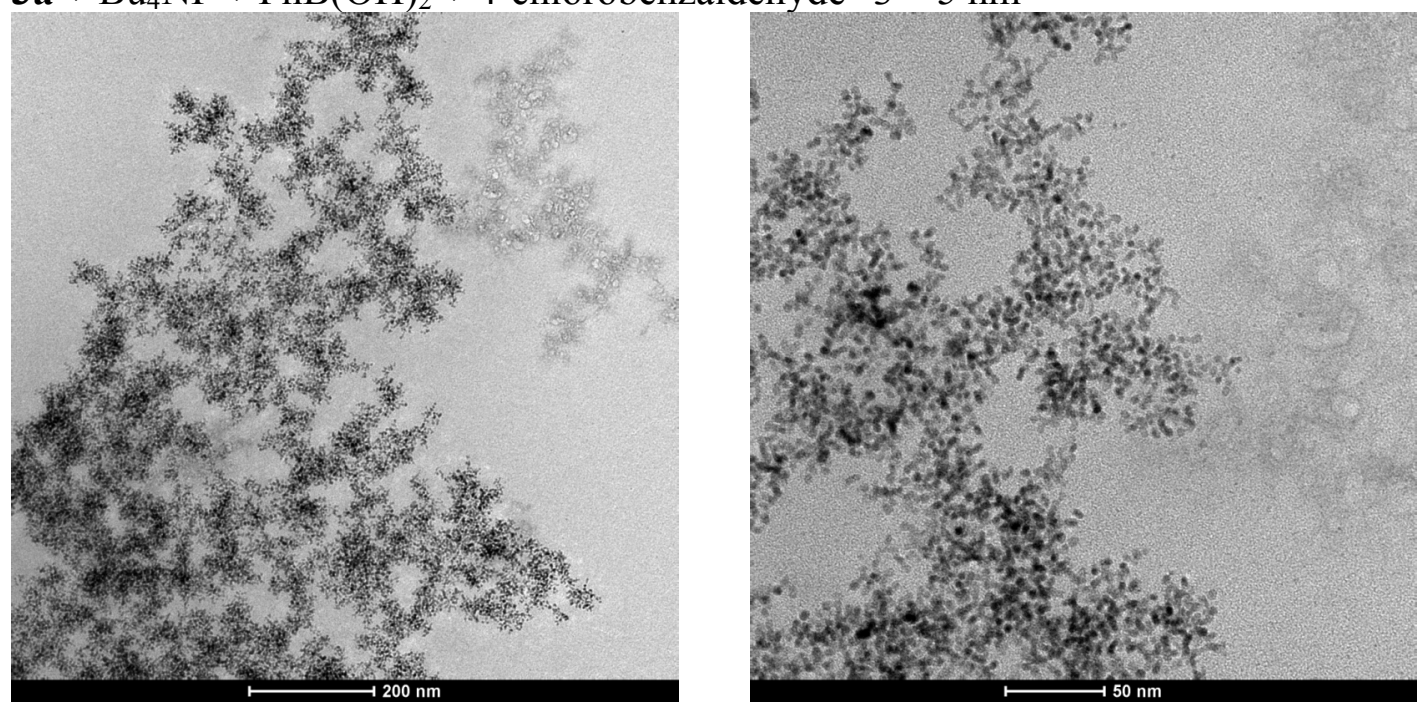
$\mathbf{3 b}+\mathrm{Bu}_{4} \mathrm{NF}+3$-bromoanisole

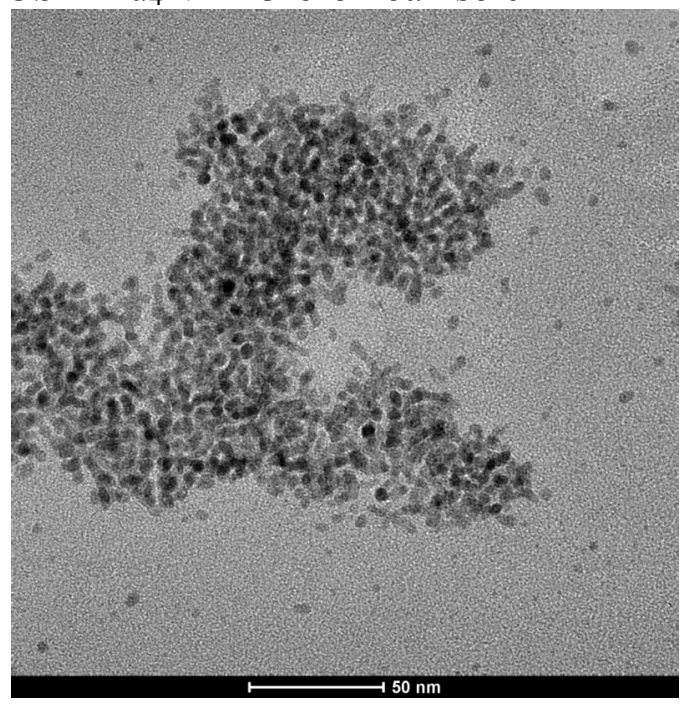

$\mathbf{3 b}+\mathrm{Bu}_{4} \mathrm{NF}+\mathrm{PhB}(\mathrm{OH})_{2}+3$-bromoanisole

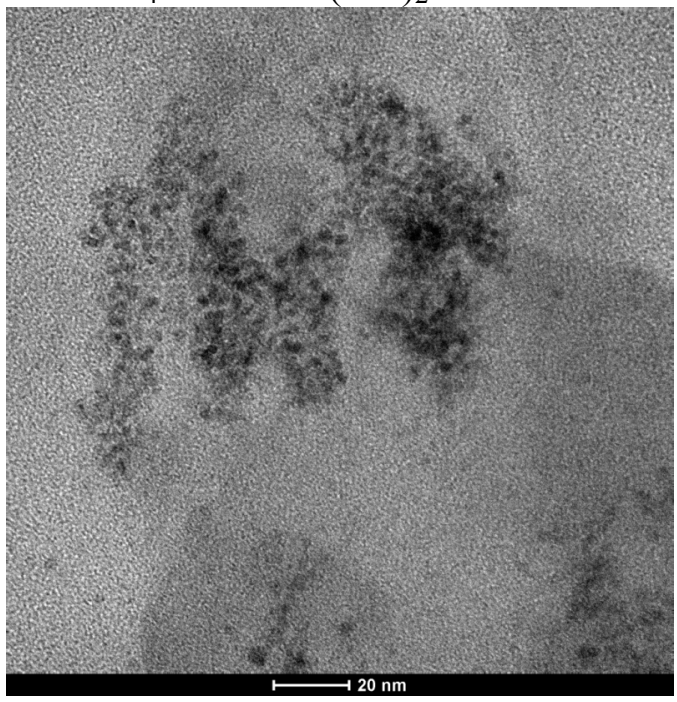

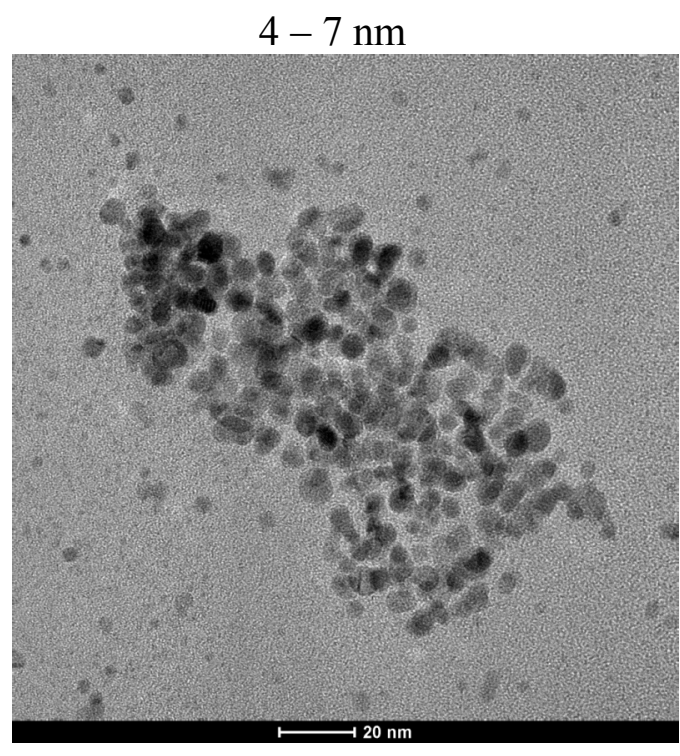

$2-3 \mathrm{~nm}$

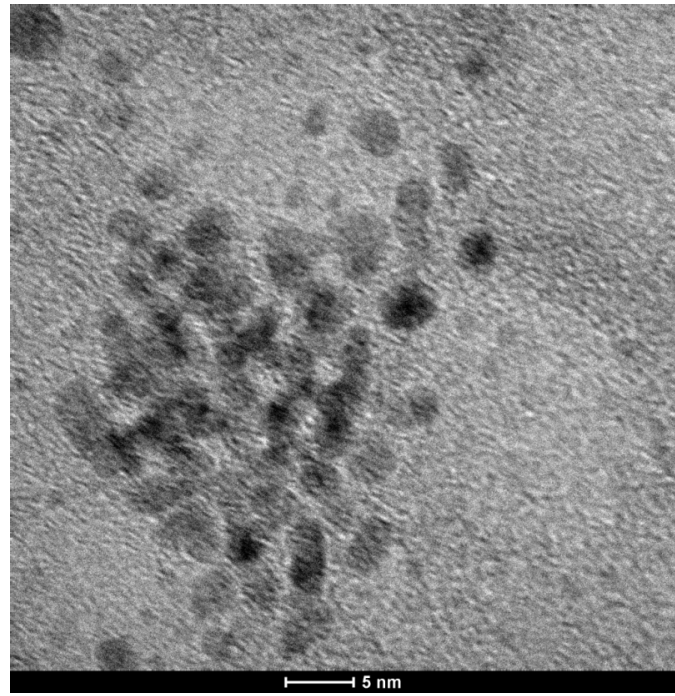



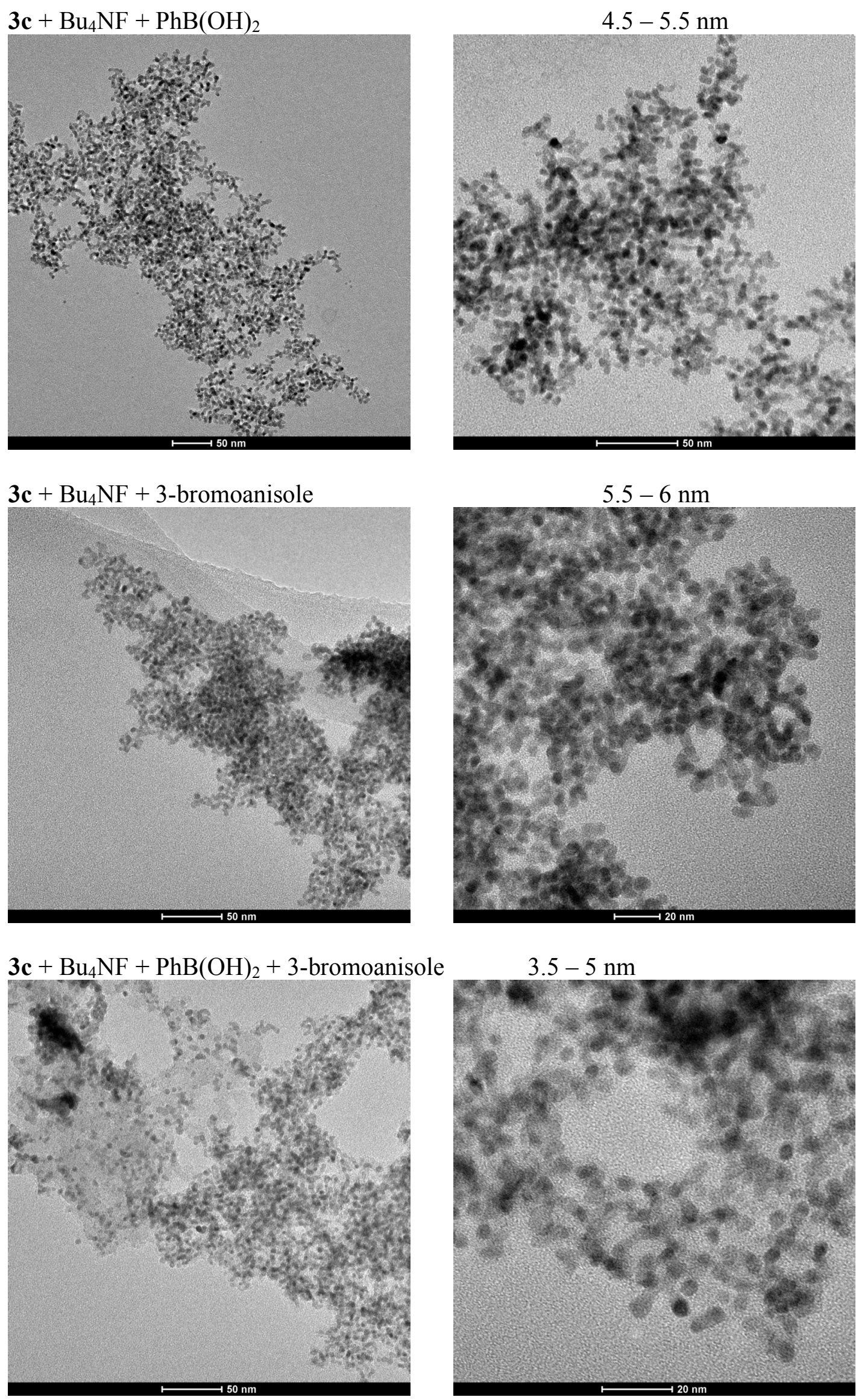

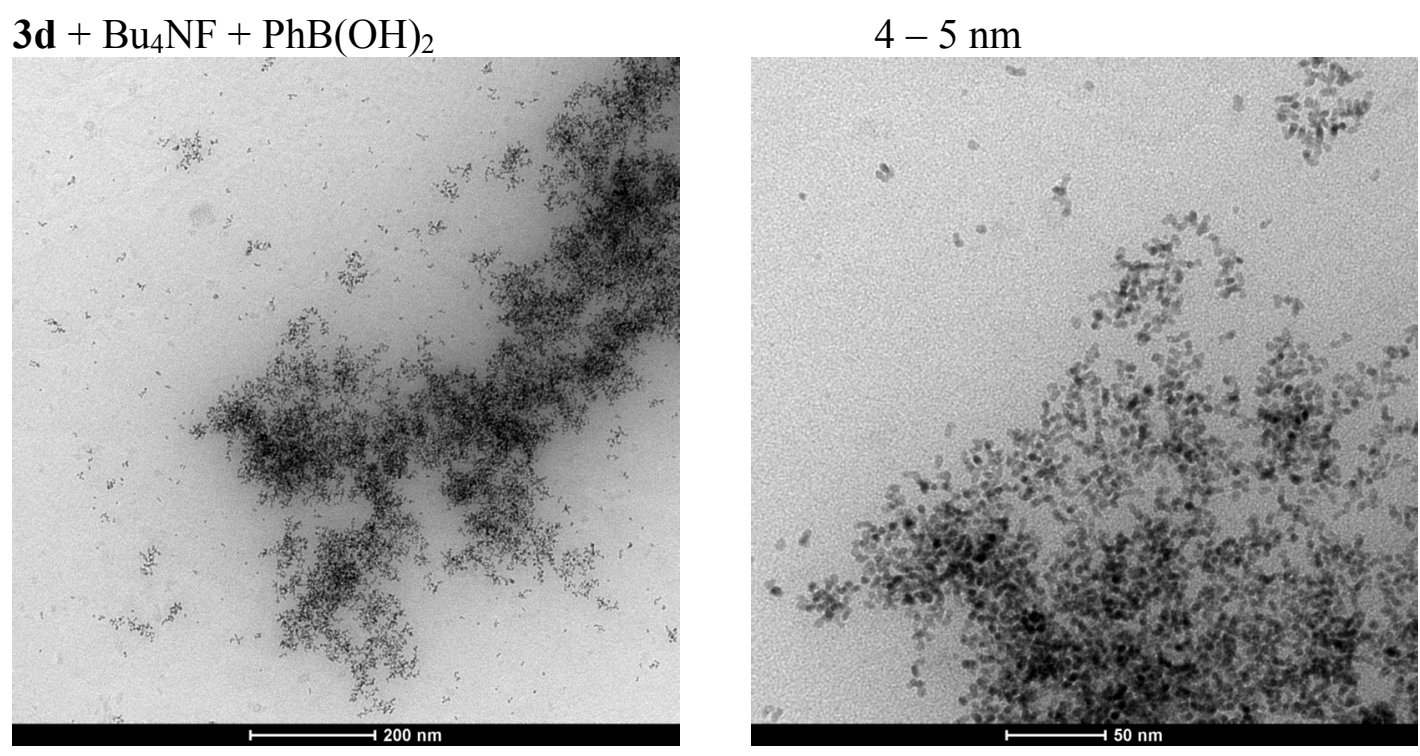

3d $+\mathrm{Bu}_{4} \mathrm{NF}+3$-bromoanisole

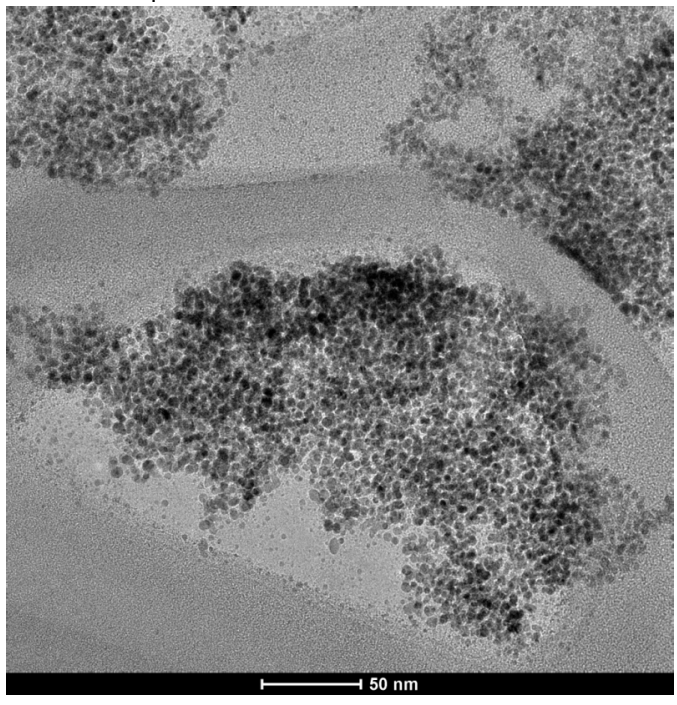

$3.5-5.5 \mathrm{~nm}$

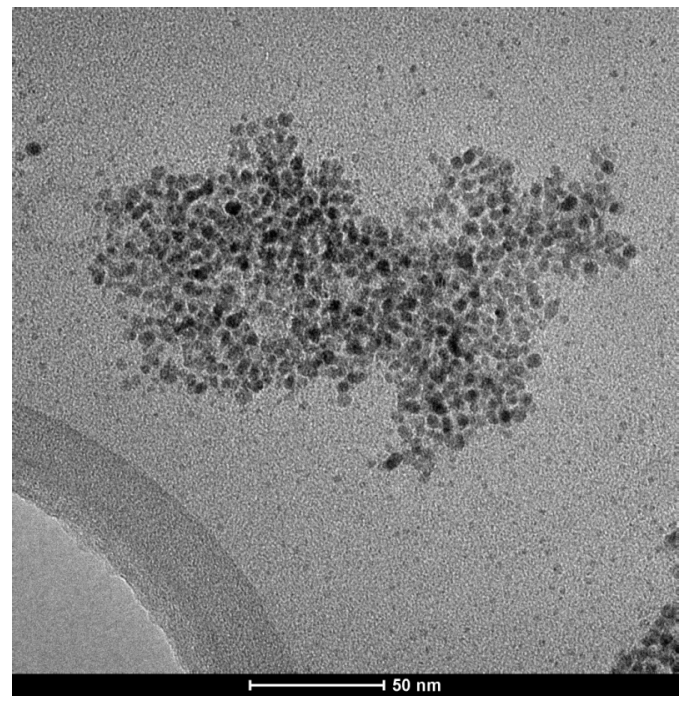



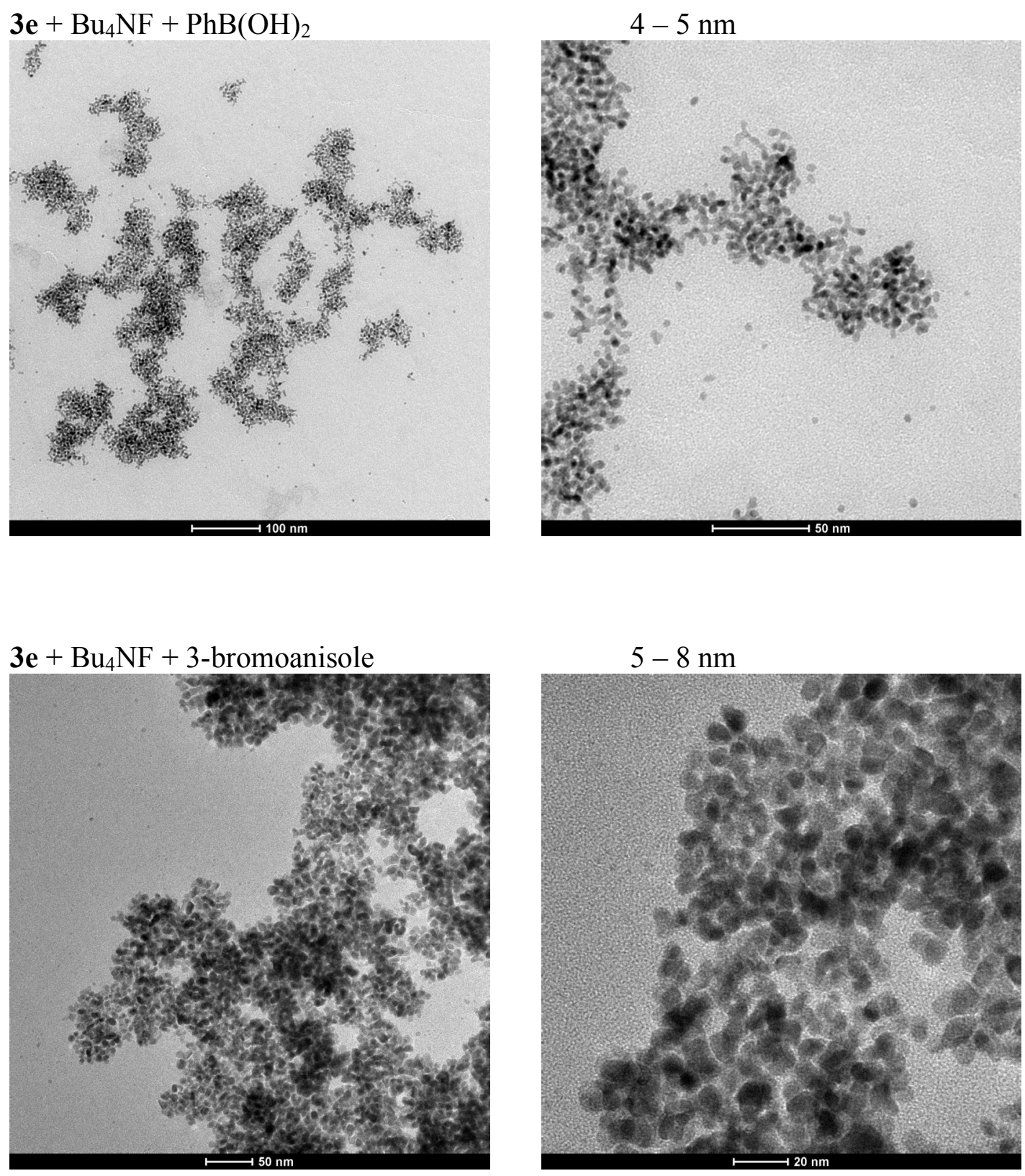


\section{Tables of Crystallographic details}

Table S1. Crystal data and structure refinement for $\mathbf{3 b}$.

\begin{tabular}{|c|c|c|}
\hline CCDC No. & \multicolumn{2}{|l|}{855568} \\
\hline Empirical formula & \multicolumn{2}{|l|}{$\mathrm{C}_{16} \mathrm{H}_{17} \mathrm{~N}_{4} \mathrm{Cl}_{3} \mathrm{Pd}$} \\
\hline Formula weight & \multicolumn{2}{|l|}{478.09} \\
\hline Temperature & \multicolumn{2}{|l|}{$100(2) \mathrm{K}$} \\
\hline Wavelength & \multicolumn{2}{|l|}{$0.71073 \AA$} \\
\hline Crystal system & \multicolumn{2}{|l|}{ Monoclinic } \\
\hline Space group & \multicolumn{2}{|l|}{$\mathrm{P} 2{ }_{1} / \mathrm{n}(\# 14)$} \\
\hline \multirow[t]{3}{*}{ Unit cell dimensions } & $\mathrm{a}=9.5092(1) \AA$ & $\alpha=90^{\circ}$ \\
\hline & $\mathrm{b}=15.4731(2) \AA$ & $\beta=90.474(1)^{\circ}$ \\
\hline & $c=12.6443(2) \AA$ & $\gamma=90^{\circ}$ \\
\hline Volume & \multicolumn{2}{|l|}{$1860.38(4) \AA^{3}$} \\
\hline Z & \multicolumn{2}{|l|}{4} \\
\hline Density (calculated) & \multicolumn{2}{|l|}{$1.707 \mathrm{Mg} \mathrm{m}^{-3}$} \\
\hline Absorption coefficient & \multicolumn{2}{|l|}{$1.433 \mathrm{~mm}^{-1}$} \\
\hline $\mathrm{F}(000)$ & \multicolumn{2}{|c|}{952} \\
\hline Crystal size & \multicolumn{2}{|c|}{$0.2728 \times 0.2184 \times 0.1121 \mathrm{~mm}^{3}$} \\
\hline Theta range for data collection & \multicolumn{2}{|c|}{3.39 to $29.75^{\circ}$} \\
\hline Index ranges & \multicolumn{2}{|c|}{$-12<=\mathrm{h}<=13,-21<=\mathrm{k}<=21,-17<=\mathrm{l}<=17$} \\
\hline Reflections collected & \multicolumn{2}{|c|}{39959} \\
\hline Independent reflections & \multicolumn{2}{|c|}{$4931[\mathrm{R}(\mathrm{int})=0.0356]$} \\
\hline Completeness to theta $=28.00^{\circ}$ & \multicolumn{2}{|c|}{$99.3 \%$} \\
\hline Absorption correction & \multicolumn{2}{|l|}{ Analytical } \\
\hline Max. and min. transmission & \multicolumn{2}{|c|}{0.888 and 0.767} \\
\hline Refinement method & \multicolumn{2}{|c|}{ Full-matrix least-squares on $\mathrm{F}^{2}$} \\
\hline Data / restraints / parameters & \multicolumn{2}{|c|}{$4931 / 0 / 219$} \\
\hline Goodness-of-fit on $\mathrm{F}^{2}$ & \multicolumn{2}{|c|}{1.059} \\
\hline Final $R$ indices $[\mathrm{I}>2 \operatorname{sigma}(\mathrm{I})]$ & \multicolumn{2}{|c|}{$\mathrm{R} 1=0.0225, \mathrm{wR} 2=0.0446$} \\
\hline $\mathrm{R}$ indices (all data) & \multicolumn{2}{|c|}{$\mathrm{R} 1=0.0304, \mathrm{wR} 2=0.0480$} \\
\hline Largest diff. peak and hole & \multicolumn{2}{|c|}{0.457 and -0.582 e $\AA^{-3}$} \\
\hline
\end{tabular}


Table S2. Crystal data and structure refinement for $\mathbf{3 c}$.

\begin{tabular}{|c|c|c|}
\hline CCDC No. & \multicolumn{2}{|l|}{855569} \\
\hline Empirical formula & \multicolumn{2}{|l|}{$\mathrm{C}_{16} \mathrm{H}_{25} \mathrm{~N}_{4} \mathrm{Cl}_{3} \mathrm{Pd}$} \\
\hline Formula weight & \multicolumn{2}{|l|}{486.15} \\
\hline Temperature & \multicolumn{2}{|l|}{$100(2) \mathrm{K}$} \\
\hline Wavelength & \multicolumn{2}{|l|}{$0.71073 \AA$} \\
\hline Crystal system & \multicolumn{2}{|l|}{ Monoclinic } \\
\hline Space group & \multicolumn{2}{|l|}{$\mathrm{P} 2_{1} / \mathrm{c}(\# 14)$} \\
\hline \multirow[t]{3}{*}{ Unit cell dimensions } & $\mathrm{a}=11.8457(1) \AA$ & $\alpha=90^{\circ}$ \\
\hline & $\mathrm{b}=9.02698(7) \AA$ & $\beta=106.0668(8)^{\circ}$ \\
\hline & $c=19.7347(2) \AA$ & $\gamma=90^{\circ}$ \\
\hline Volume & \multicolumn{2}{|l|}{$2027.82(3) \AA^{3}$} \\
\hline Z & \multicolumn{2}{|l|}{4} \\
\hline Density (calculated) & \multicolumn{2}{|l|}{$1.592 \mathrm{Mg} \mathrm{m}^{-3}$} \\
\hline Absorption coefficient & \multicolumn{2}{|l|}{$1.316 \mathrm{~mm}^{-1}$} \\
\hline $\mathrm{F}(000)$ & \multicolumn{2}{|l|}{984} \\
\hline Crystal size & \multicolumn{2}{|c|}{$0.2170 \times 0.1338 \times 0.1227 \mathrm{~mm}^{3}$} \\
\hline Theta range for data collection & \multicolumn{2}{|c|}{3.24 to $30.99^{\circ}$} \\
\hline Index ranges & \multicolumn{2}{|c|}{$-17<=\mathrm{h}<=17,-13<=\mathrm{k}<=13,-28<=\mathrm{l}<=28$} \\
\hline Reflections collected & \multicolumn{2}{|c|}{61720} \\
\hline Independent reflections & \multicolumn{2}{|c|}{$6454[\mathrm{R}($ int $)=0.0314]$} \\
\hline Completeness to theta $=30.99^{\circ}$ & \multicolumn{2}{|c|}{$99.8 \%$} \\
\hline Absorption correction & \multicolumn{2}{|l|}{ Analytical } \\
\hline Max. and min. transmission & \multicolumn{2}{|c|}{0.884 and 0.807} \\
\hline Refinement method & \multicolumn{2}{|c|}{ Full-matrix least-squares on $\mathrm{F}^{2}$} \\
\hline Data / restraints / parameters & \multicolumn{2}{|c|}{$6454 / 0 / 220$} \\
\hline Goodness-of-fit on $\mathrm{F}^{2}$ & \multicolumn{2}{|l|}{1.067} \\
\hline Final $R$ indices $[\mathrm{I}>2 \operatorname{sigma}(\mathrm{I})]$ & \multicolumn{2}{|c|}{$\mathrm{R} 1=0.0193, \mathrm{wR} 2=0.0451$} \\
\hline $\mathrm{R}$ indices (all data) & \multicolumn{2}{|c|}{$\mathrm{R} 1=0.0252, \mathrm{wR} 2=0.0489$} \\
\hline Largest diff. peak and hole & \multicolumn{2}{|c|}{0.569 and -0.528 e $\AA^{-3}$} \\
\hline
\end{tabular}


Table S3. Crystal data and structure refinement for 3d.

\begin{tabular}{ll}
\hline CCDC No. & 855567 \\
Empirical formula & $\mathrm{C}_{23.32 \mathrm{H}_{23.68} \mathrm{~N}_{4} \mathrm{O}_{0.18} \mathrm{Cl}_{3.97} \mathrm{Pd}}$ \\
Molecular formula & $\mathrm{C}_{23} \mathrm{H}_{23} \mathrm{~N}_{4} \mathrm{Cl}_{3} \mathrm{Pd} \times 0.32\left(\mathrm{CHCl}_{3}\right) \times 0.18\left(\mathrm{H}_{2} \mathrm{O}\right)^{\mathrm{a})}$ \\
Formula weight & 609.90 \\
Temperature & $100(2) \mathrm{K}$ \\
Wavelength & $0.71073 \AA$ \\
Crystal system & Triclinic \\
Space group & $\mathrm{P}-1(\# 2)$ \\
Unit cell dimensions & $\mathrm{a}=12.3460(1) \AA \quad \alpha=69.0950(8)^{\circ}$ \\
& $\mathrm{b}=15.1768(1) \AA \quad \beta=72.0493(8)^{\circ}$ \\
& $\mathrm{c}=15.6626(2) \AA \quad \quad \gamma=83.6232(6)^{\circ}$ \\
Volume & $2608.11(4) \AA^{3}$ \\
$\mathrm{Z}$ & 4 \\
Density (calculated) & $1.553 \mathrm{Mg} \mathrm{m}{ }^{-3}$ \\
Absorption coefficient & $1.138 \mathrm{~mm}{ }^{-1}$ \\
$\mathrm{~F}(000)$ & 1226.4 \\
Crystal size & $0.2800 \times 0.2492 \times 0.1607 \mathrm{~mm}^{3}$ \\
Theta range for data collection & 3.35 to $26.38^{\circ}$ \\
Index ranges & $-15<=\mathrm{h}<=15,-18<=\mathrm{k}<=18,-19<=1<=19$ \\
Reflections collected & 47073 \\
Independent reflections & $10652[\mathrm{R}(\mathrm{int})=0.0374]$ \\
Completeness to theta $=26.38^{\circ}$ & $99.8 \%$ \\
Absorption correction & Analytical \\
Max. and min. transmission & 0.868 and 0.768 \\
Refinement method & Full-matrix least-squares on $\mathrm{F}^{2}$ \\
Data / restraints / parameters & $10652 / 0 / 613$ \\
Goodness-of-fit on $\mathrm{F}^{2}$ & 1.044 \\
Final R indices [I $>2$ sigma(I) & $\mathrm{R} 1=0.0362, \mathrm{wR} 2=0.0841$ \\
$\mathrm{R}$ indices (all data) & $\mathrm{R} 1=0.0474, \mathrm{wR} 2=0.0913$ \\
Largest diff. peak and hole & 1.840 and $-0.868 \mathrm{e} \AA^{-3}$ \\
\hline
\end{tabular}

${ }^{\text {a) }}$ The hydrogen atoms of the water molecule could not be detected. 


\section{References}

[S1] P. Appukkuttana, W. Dehaena, V. Fokin, M. Van der Eycken, Org Lett. 2004, 6, 42234225.

[S2] (a) K. Barral D. A. Moorhouse, J. E. Moses, Org Lett. 2007, 9, 1809-1811. (b) D. Kumar, V. B. Reddy, Synthesis 2010, 1687-1691.

[S3] A. Poulain, D. Canseco-Gonzalez, R. Hynes-Roche, H. Müller-Bunz, O. Schuster, H. Stoeckli-Evans, A. Neels, M. Albrecht, Organometallics, 2011, 30, 1021-1029. 